\title{
Graben width controlling syn-rift sedimentation: the Palaeogene southern Upper Rhine Graben as an example
}

\author{
Sebastian Hinsken · Kamil Ustaszewski • \\ Andreas Wetzel
}

Received: 30 July 2005/ Accepted: 15 August 2006/Published online: 18 April 2007

(C) Springer-Verlag 2007

\begin{abstract}
Eocene to Early Oligocene syn-rift deposits of the southern Upper Rhine Graben (URG) accumulated in restricted environments. Sedimentation was controlled by local clastic supply from the graben flanks, as well as by strong intra-basinal variations in accommodation space due to differential tectonic subsidence, that in turn led to pronounced lateral variations in depositional environment. Three large-scale cycles of intensified evaporite sedimentation were interrupted by temporary changes towards brackish or freshwater conditions. They form three major base level cycles that can be traced throughout the basin, each of them representing a stratigraphic sub-unit. A relatively constant amount of horizontal extension $(\Delta L)$ in the range of 4$5 \mathrm{~km}$ has been estimated for the URG from numerous cross-sections. The width of the $\operatorname{rift}\left(L_{f}\right)$, however, varies between 35 and more than $60 \mathrm{~km}$, resulting in a variable crustal stretching factor between the bounding masterfaults. Apart from block tilting, tectonic subsidence was, therefore, largely controlled by changes in the initial rift width $\left(L_{0}\right)$. The along-strike variations of the graben width are responsible for the development of a deep, trough-like evaporite basin (Potash Basin) in the narrowest part of the southern URG, adjacent to shallow areas in the wider parts of the rift such as the Colmar Swell in the north and the Rhine Bresse Transfer Zone that delimits the URG to the south. Under a constant amount of extension, the along-strike variation in rift width is the principal factor controlling depo-centre development in extensional basins.
\end{abstract}

S. Hinsken $(\bowtie) \cdot$ K. Ustaszewski · A. Wetzel

Geologisch-Paläontologisches Institut, Universität Basel,

Bernoullistrasse 32, 4056 Basel, Switzerland

e-mail: s.hinsken@gmx.de
Keywords Upper Rhine Graben · Syn-rift sedimentation · Genetic stratigraphy · Crustal extension $\cdot$ Stretching factor

\section{Introduction}

The Upper Rhine Graben (URG) forms the central part of the Cenozoic Central European Rift System, traversing Europe from the Mediterranean to the North Sea (e.g. Dèzes et al. 2004; Fig. 1). Graben formation is thought to have resulted from uniform crustal extension, involving the reactivation of numerous pre-existing faults under a temporally changing stress regime (Illies and Greiner 1978; Schumacher 2002). However, the URG comprises several sub-basins showing distinct differences in terms of amount and timing of subsidence, and hence of sediment fill (Sittler 1969; Sissingh 1998).

In the URG intense exploration for hydrocarbons and potash salts has yielded a large data set (drillings, seismic lines) that has become accessible during the last decade. Due to Neogene uplift and erosion, the rift flanks and marginal parts of the basin are exposed and accessible for field investigations. Numerous recent studies have provided new insights into the basin architecture and graben evolution (e.g. Schumacher 2002; Derer et al. 2003; Berger et al. 2005a, b; Le Carlier de Veslud et al. 2005; Rotstein et al. 2005; Ustaszewski et al. 2005a). Nonetheless, the URG is lacking 3D seismic coverage and many aspects concerning the age and timing of crustal movements, the palaeogeography and the thermal history are still a matter of debate.

In the light of newly available data the sedimentary record of the URG has been reviewed applying the new concept of genetic stratigraphy (sensu Cross and 


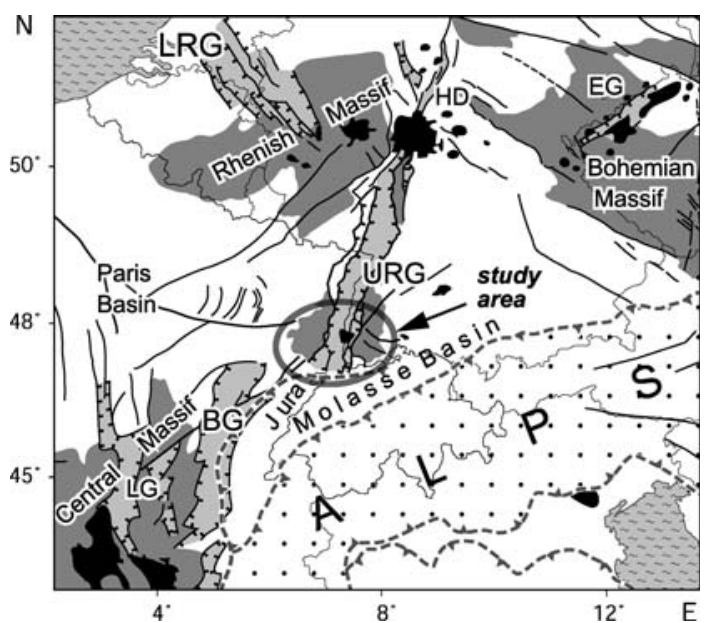

Fig. 1 The southern part of the URG (encircled) occupies a central position within the Central European Rift System. Rift basins (light grey): $B G$ Bresse Graben, EG Eger Graben, $H D$ Hessian Depression, $L R G$ Lower Rhine Graben, $U R G$ Upper Rhine Graben; Cenozoic volcanics (black); the Variscan massifs (dark grey) are bounded by inherited faults (black lines) and Tertiary rifts (modified from Dèzes et al. 2004)

Lessenger 1998). Since such investigations address quantitative aspects of sedimentation, they may provide important information about tectonic graben development. Additionally, graben volume, extension and crustal stretching factors have been estimated using two new cross-sections, located in different parts of the area, and some published cross-sections across the northern URG have been re-evaluated. A detailed basin analysis can elucidate how sedimentation was affected by "syn-rift" tectonic movements and thus contributes valuable information on rifting dynamics (e.g. Leeder and Gawthorpe 2002).

The purpose of this study is to outline the tectonosedimentary basin evolution of the southern URG during the late Middle Eocene to Early Oligocene main rifting phase. Special attention is paid to the along-strike variations in the crustal stretching factor $\beta$ and to the basic relationships between sedimentation and tectonics during extensional basin development.

\section{Geological context}

\section{Study area}

The study area comprises the southern part of the URG, between the Colmar Swell in the north and the Jura Mountains in the south (Figs. 2, 3, 4). Today the area is an elevated zone that covers the watersheds between the North Sea (Rhine) and the Black Sea (Danube) as well as the North Sea and the Mediterranean (Doubs)
(Fig. 3). This regional topographic dome coincides with a decreased crustal thickness of $24 \mathrm{~km}$ below the Mulhouse Potash Salt Basin (Potash Basin).

The eastern and western parts of the southern URG show a slight asymmetry. The western part represents an elongated half graben, while the eastern part is dissected into a number of antithetic blocks (Fig. 4). The Vosges to the west and the Black Forest to the east form the graben shoulders of the southern URG; on both sides the crystalline basement is exposed. Towards the south the graben is delimited by the frontal folds of the Jura Mountains. Within the study area four structural domains are distinguished (Fig. 2):

Potash Basin (Fig. 4a; e.g. Courtot et al. 1972; Blanc-Valleron and Schuler 1997); it represents the depo-centre of the southern URG. There, up to $1,800 \mathrm{~m}$ thick evaporites and marls accumulated during the late Middle Eocene to Early Oligocene main rifting stage. The salt partly forms diapirs and the basin fill is overprinted by salt tectonics resulting in shallow, listric low-angle detachments as well as block tilting and bending of incompetent layers (see Blanc-Valleron 1991; Lutz and Cleintuar 1999). The Potash Basin is bordered to the east and west by major normal fault zones with up to several $1,000 \mathrm{~m}$ throw. In the basin interior the throw on normal faults is usually less than a few hundred metres (e.g. Bertrand et al. 2005). Two major sub-basins, one in the west and one in the east, represent the hanging-wall half grabens of the large border faults. The Wittelsheim Sub-Basin to the west extends for about $40 \mathrm{~km}$ in $\mathrm{N}-\mathrm{S}$ direction between Colmar and Mulhouse. The Buggingen Sub-Basin to the east extends for about $15 \mathrm{~km}$ in $\mathrm{N}-\mathrm{S}$ direction between the Freiburg Embayment and the Klemmbach Fault (Fig. 2).

Colmar Swell and Freiburg Embayment delimit the Potash Basin to the north. They are characterized by relatively thin syn-rift deposits. The Colmar Swell forms an elevation, crossing the URG obliquely between Colmar and north of the Kaiserstuhl, where it passes into the northern part of the Freiburg Embayment.

Tilted Block Array between Belfort and Bad Säckingen (Figs. 2, 4b); it is located at the southern end of the URG. The transfer zone between Mulhouse and the Wehra-Zeiningen Fault marks the transition to the Potash Basin (Fig. 2). The Dannemarie Basin forms the southern prolongation of the Wittelsheim SubBasin (e.g. Wagner 1938) and contains the thickest synrift deposits of the southernmost graben domain. This basin changes from a symmetrical graben in the north to a half graben in the south. The Tilted Block Array rises progressively towards the eastern graben shoul- 
Fig. 2 Schematic geological map of the southern URG.

The depo-centre of the

Mulhouse Potash Salt Basin (Potash Basin) is located in the narrowest part of the graben that is flanked by the highest mountains of the Vosges and Black Forest. Towards the south the graben widens considerably to the Tilted Block Array where it is bordered by the Jura Mountains

Fig. 3 Digital elevation map of the study area on which a simplified fault grid and isopaches of graben fill (broken lines; thickness in $\mathrm{m}$ ) have been superimposed. This part of the graben was strongly uplifted and exposed during the Neogene. The area forms an intra-continental high, gathering the watersheds between the North Sea, the Black Sea and the Mediterranean
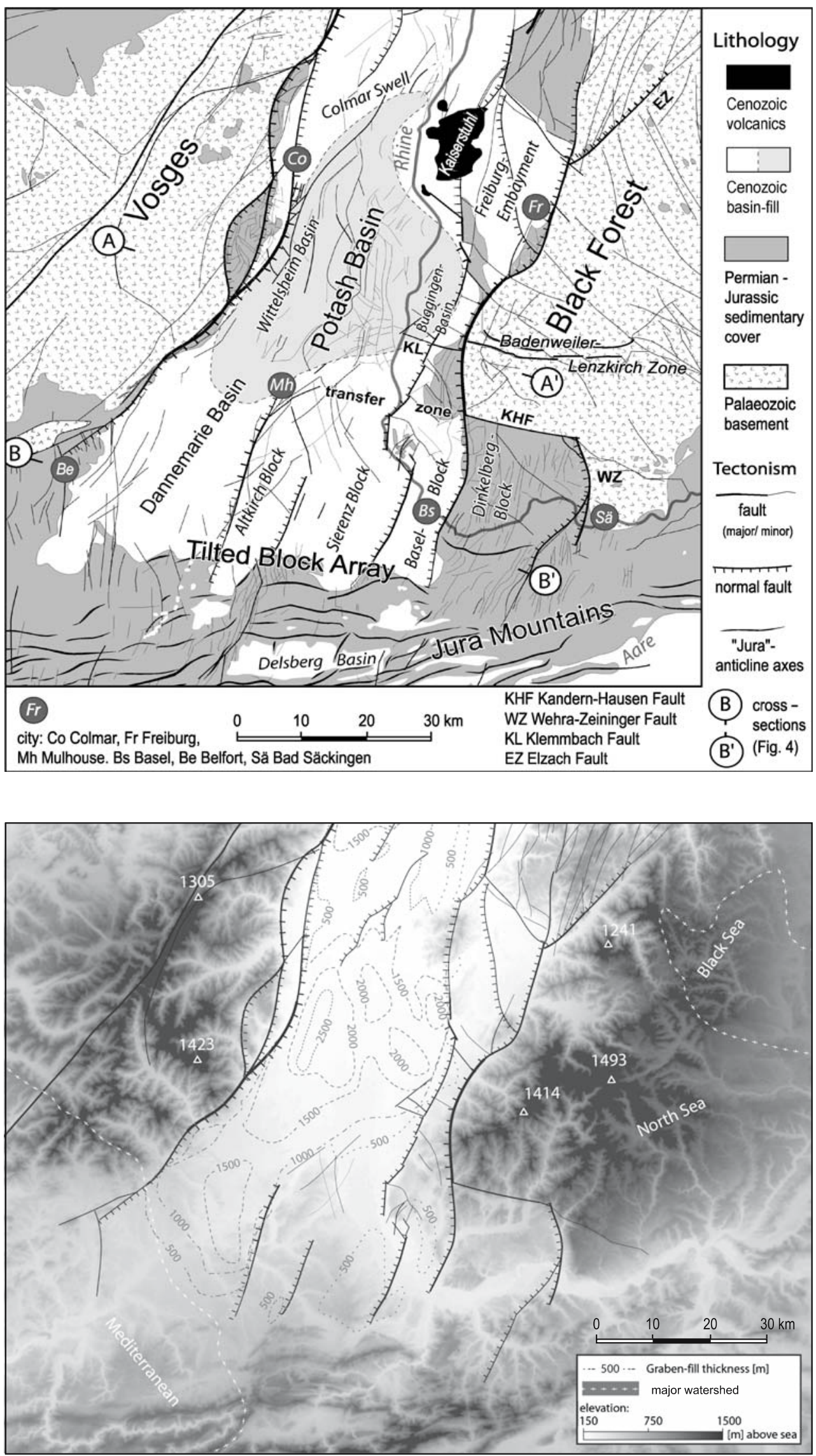


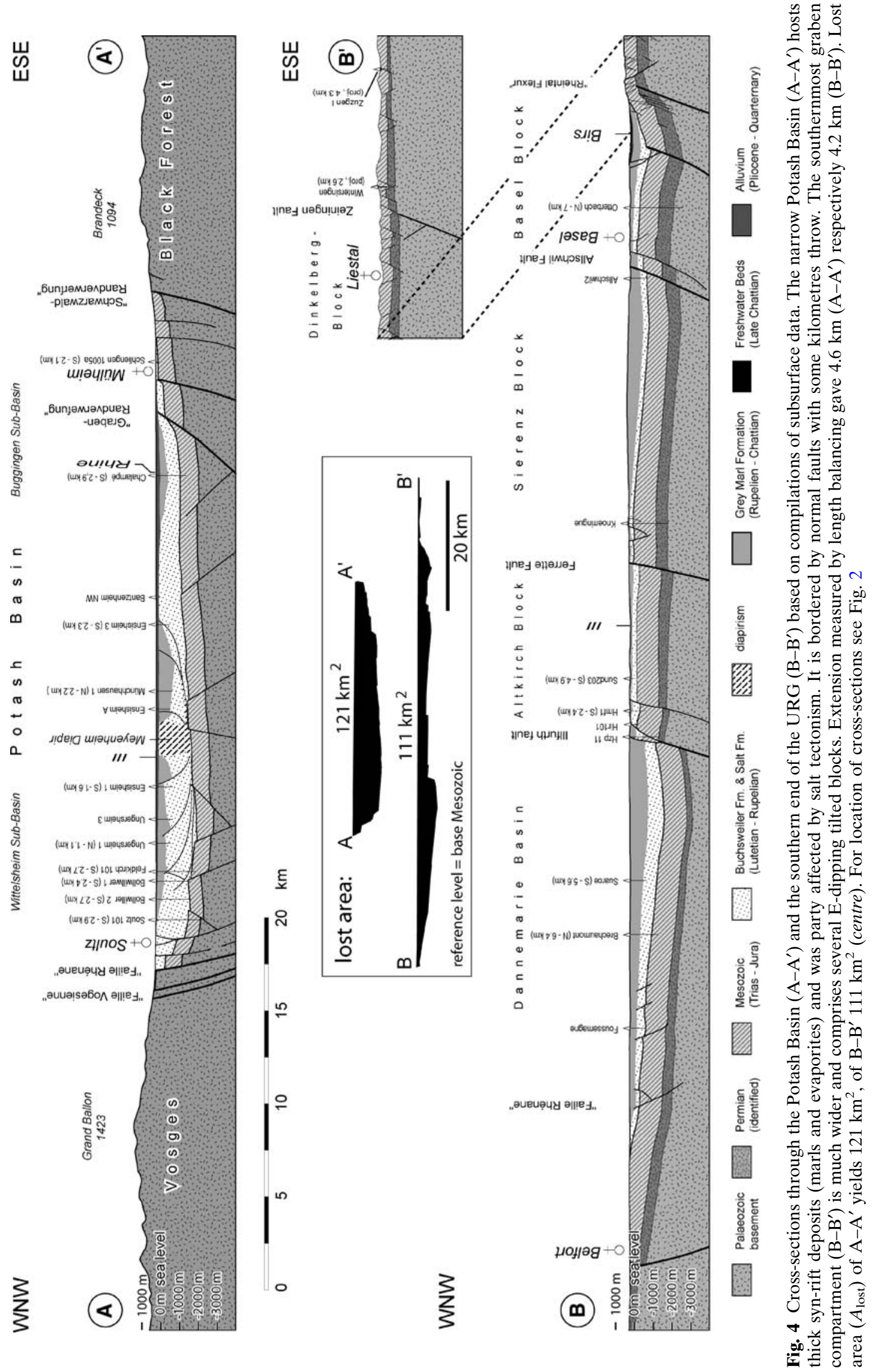


der. It comprises from $\mathrm{W}$ to $\mathrm{E}$ the southern Dannemarie Basin (Le Carlier de Veslud et al. 2005), Altkirch Block, Sierentz Block (Rotstein et al. 2005), Basel Block and Dinkelberg Block. In map view, the hanging wall half grabens of these blocks appear as Tertiary filled embayments that encroach onto the front of the Jura Mountains (Fig. 2). A mosaic of small fault blocks occupies the western part of the MulhouseWehra Transfer Zone. In the east, however, this zone is represented by a distinct dextral tear fault, the Kandern-Hausen Fault. This fault juxtaposes the Dinkelberg Block against the Black Forest and forms the connection between the Black Forest Border Fault and the Wehra-Zeiningen Fault.

Jura Mountains; they consist of Mesozoic pre-rift series and contain several small Tertiary basins, such as the Laufen Basin and the Delsberg Basin (e.g. Laubscher 1998; Berger et al. 2005a). During the Palaeogene these basins were occasionally connected to the southern URG and/or to the Molasse Basin (e.g. Berger et al. 2005a). Palaeogene deposits onlap onto monoclines of pre-rift series at the southern end of the graben and hence document its stable position since that time (Ustaszewski et al. 2005a). The southern end of the URG forms part of the so-called Rhine Bresse Transfer Zone (RBTZ), along which crustal extension across the URG was transferred via a diffuse zone to the Bresse Graben (e.g. Laubscher 1970; Illies 1981; Ustaszewski et al. 2005b).

\section{Graben evolution}

\section{Palaeozoic basement configuration}

The basement below the URG is part of the Variscan internides comprising several terranes (e.g. Franke 1989). Pre-existing faults within the crystalline basement were reactivated during the formation of the URG (e.g. Schumacher 2002). They had originally developed during the late phases of the Variscan orogeny (e.g. Cloos 1939), as well as during Late Palaeozoic wrench tectonics that led to the development of several transtensional intramontane basins, the socalled Permo-Carboniferous Troughs (e.g. Ziegler 1990; Wetzel et al. 2003) and fault zones, including the NNE-trending "Rhenish Lineament" (Boigk and Schöneich 1970).

The Permo-Carboniferous Burgundy Trough (e.g. Boigk and Schöneich 1970) underlies the area of the RBTZ, the northern Jura Mountains and the adjacent part of the southern URG (Ustaszewski et al. 2005a). In many instances, Cenozoic graben structures and Palaeozoic basement structures coincide spatially. The
Potash Basin, for instance, is bordered to the SE by the Klemmbach Fault (Schnarrenberger 1925), forming the prolongation of the E-W striking Badenweiler-Lenzkirch Zone (Wagner 1938). This zone has been interpreted as a Variscan suture (Löschke et al. 1998). To the NE, the boundary of the Potash Basin coincides with a NW-trending dyke swarm within the basement of the Black Forest (see Metz 1970). The Dinkelberg Block, as a further example, is juxtaposed against the Black Forest along Late Palaeozoic shear zones (Echtler and Chauvet 1992).

\section{Mesozoic pre-rift sedimentation}

During the Triassic and Jurassic the study area belonged to the southern part of the epicontinental Germanic Basin, where about 1.2-1.5 km of sediments accumulated (e.g. Geyer and Gwinner 1986). Lateral facies and thickness changes of the Mesozoic sediments point to the reactivation of Palaeozoic basement structures (Wetzel et al. 2003; Ziegler et al. 2004).

During the Triassic depositional environments changed repeatedly between continental and restricted shallow marine conditions. Evaporites formed during the Middle and Late Triassic (e.g. Geyer and Gwinner 1986). During the Jurassic predominantly shales and carbonates accumulated in a subtropical epicontinental sea. Carbonate platforms developed during the Middle Dogger and the Malm (e.g. Ziegler 1990). Cretaceous sediments are lacking in the URG area, because of non-deposition or erosion. Therefore, the area is considered a lowland close to base level during the Late Cretaceous, but this is still a matter of debate (e.g. Ziegler 1990; Müller et al. 2002; Timar-Geng et al. 2006).

\section{Cenozoic graben formation}

The earliest hint of rift-related activity is minor volcanism during the Palaeocene about $60 \mathrm{Ma}$ ago (Keller et al. 2002). Prior to rift-induced subsidence, palaeosols on top of the pre-rift sediments document weathering and denudation before Early to Middle Eocene times. Below this erosional unconformity the stratigraphic age of the Mesozoic subcrop increases generally towards the north with superimposed local domes and depressions (e.g. Sittler 1969; Fig. 5). This implies a general southward tilt of an undulating pre-rift land surface.

The oldest known syn-rift sediments in the southern URG are red iron-pisolite-bearing (feralitic) palaeosols (Siderolite Formation) and freshwater limestones (Buchsweiler Formation). Mammalian remains found 
Fig. 5 Stratigraphic chart illustrating the Cenozoic evolution of the southern URG and northern Jura Mountains (modified after Giamboni et al. 2004 and own observations; numerical ages after Gradstein et al. 2004). The Salt Formation constituting the majority of graben fill in the southern URG represents the syn-rift sediments

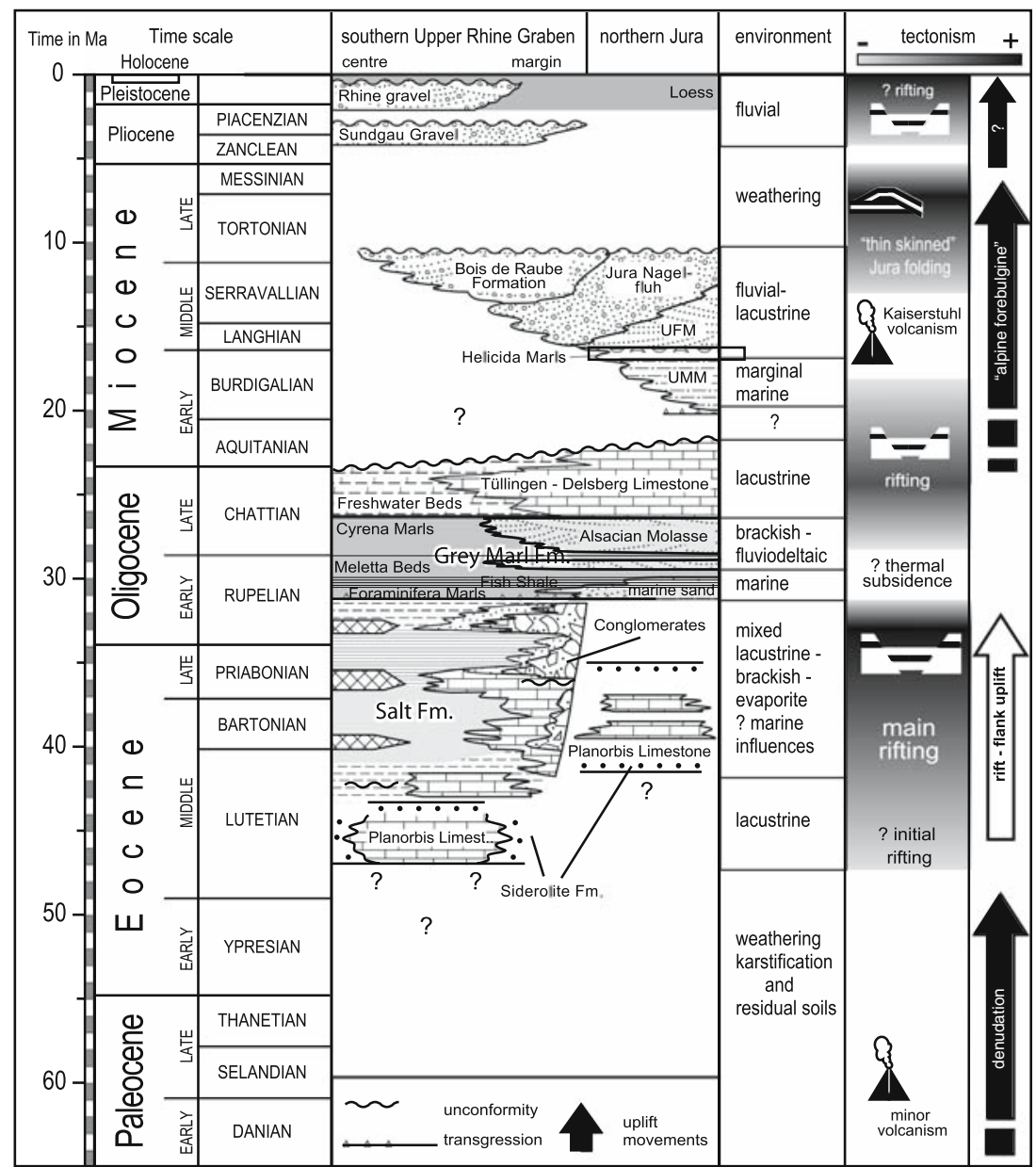

therein provided a Late Lutetian age (Schmidt-Kittler 1987). The onset of lacustrine sedimentation in the basin interior, as well as the local accumulation of residual clays in wedge-shaped grabens along the main border faults (Hinsken 2003) and within the adjacent Jura (Laubscher 2004) clearly indicate the onset of tectonic movements by the Middle Eocene at the latest.

Increased rifting during the late Middle Eocene to Early Oligocene (Lutetian-Rupelian) led to the formation of several evaporitic sub-basins, within the central and the southern URG including the Potash Basin (e.g. Blanc-Valleron and Schuler 1997). In these sub-basins the environment changed repeatedly between terrestrial, fluvial, lacustrine, brackish and evaporitic (e.g. Duringer 1988).

In the northern and central URG, deposits of that time are subdivided in the (basal) Green Marl Formation (Lymnaeenmergel) and (up-section) the Pechelbronn Beds (Pechelbronn Schichten), whereas in the southern URG deposits of that time constitute the Salt Formation (Salzfolge). The Salt-Formation represents the majority of graben-fill in the southern URG, in particular in the Potash Basin, where it contains large amounts of evaporites. Fault-related distribution of facies and thickness implies that the Salt Formation represents syn-rift sedimentation (Duringer 1988; Hauber 1991; Rotstein et al. 2005). Therefore, it is the centre of interest in this study.

During the Middle Oligocene (Late Rupelian), a marine transgression flooded the URG and the area to the south. Grey muds and sands that constitute the Grey Marl Formation (Graue Schichtenfolge) were deposited. Minor displacements along faults occurred when the Grey Marl Formation formed (Hauber 1991; Rotstein et al. 2005), while the coastline was shifted onto the graben shoulders and the northern Jura (Wittmann 1952; Ustaszewski et al. 2005a). This suggests decreased rifting and the onset of increased thermal subsidence (Hinsken 2003; Rotstein et al. 2005). The Foraminifera Marl Member (Foraminiferenmergel) at the base is overlain by the black shales of the Fish Shale Member (Fischschiefer). Laterally both pass into calcarenites of local origin at the southern 
end of the graben, the Marine Sand Member, interpreted as littoral facies (Meeressand; Fischer 1969). A rich fauna indicates open marine conditions and water depths of more than $200 \mathrm{~m}$ (Huber 1994). Up-section, the Meletta Shale Member (Melettaschichten) contains, particularly in its lower part, Alpine-derived Molassetype sandstones, implying a connection with the "overfilled" Molasse Basin (Kuhlemann et al. 1999). Decreased faunal diversity implies prevailing deposition under brackish-marine conditions, but still with water depths of about $100 \mathrm{~m}$ (Huber 1994). The overlying Cyrena Marl Member (Cyrenenmergel) accumulated under marine, brackish and freshwater conditions. Towards the Jura it interfingers with fluviodeltaic Molasse-type sandstones of the Alsacian Molasse Member (Elsässer Molasse), which are correlated with the Lower Freshwater Molasse (Kuhlemann et al. 1999).

Freshwater sedimentation prevailed inside the URG until the end of the Oligocene (Rollier 1911). Relics of these almost completely eroded deposits have been described from the Potash Basin, the SE part of the graben (Tüllingen Beds; Tüllinger Schichten) and the Jura Mountains (Delsberg Limestone; Calcaires Délemontiens); there, deposition continued until the Early Miocene (Berger et al. 2005a).

Sediments of Early Miocene age have not been found in the southern part of the URG, whereas approximately $1 \mathrm{~km}$ thick brackish deposits are preserved in the northern URG implying increased subsidence there (Derer et al. 2003). It is still a matter of debate, to which extent the lack of sediments younger than Early Aquitanian in the southern URG is due to non-deposition (discussed by Schumacher 2002) and/or major erosion after the Early Miocene (e.g. Sissingh 1998; Lutz and Cleintuar 1999). However, major sediment accumulation after the Early Miocene is highly unlikely for the following reasons:

1. The (Burdigalian) Upper Marine Molasse of the Alpine foreland basin wedges out towards the north within the Jura Mountains (e.g. Berger et al. 2005a), suggesting that the southern URG was uplifted above the regional base level during this time.

2. The Middle Miocene volcanics of the Kaiserstuhl rest unconformably on faulted and deeply truncated Late Oligocene sediments (Wimmenauer 1977).

3. Salt diapirs are restricted to the Lower Salt SubFormation (e.g. Larroque and Ansart 1984; BlancValleron and Schuler 1997). As the development of diapirs requires a considerable overburden, the lack of diapirism within the Upper Salt Sub-Formation implies that Neogene sediments did not accumulate in considerable thickness $(>100 \mathrm{~m})$.

4. High resolution reflection seismic data recorded on the river Rhine show a major erosional unconformity between the Plio-Pleistocene gravels and the Palaeogene graben fill sediments (P. Ziegler, personal communication).

5. Mean random vitrinite reflectance (\%Rr) measured on Oligocene samples from the southernmost URG and the Delsberg Basin indicate low thermal maturity (Todorov et al. 1993).

During the Middle Miocene, the area of the southern URG was emergent due to lithosphere-scale folding contemporaneous with volcanic activity in the Kaiserstuhl (e.g. Ziegler et al. 2004). The concomitant uplift and exhumation of the graben shoulders is documented by conglomerates of Middle Miocene age, the so-called "Jura Nagelfluh", which were transported southward into the northern Jura (e.g. Laubscher 2001; Berger et al. 2005a). However, the lack of Early Miocene deposits in the southern URG implies that uplift could have already started in the Early Miocene (Schumacher 2002).

During the Late Miocene to Early Pliocene the Jura was thrust and folded (Kälin 1997; Becker 2000; Giamboni et al. 2004). During the Early Pliocene (4.3 Ma), Alpine rivers entered the southern URG at its southeastern corner, flowed to the west and drained via Bresse and Rhone Grabens into the Mediterranean, depositing the so-called "Sundgau-Gravel" (Manz 1934). During the Late Pliocene drainage changed to the modern pattern (Villinger 1998; Giamboni et al. 2004).

\section{Syn-rift sedimentation}

The Salt Formation comprises the syn-rift sediments of the southern URG, whereas the overlying Grey Marls probably represent the late syn-rift or even the post-rift stage (e.g. Rotstein et al. 2005). The Salt Formation consists of three sub-formations and several members (Fig. 5; see also Fig. 12). Due to the rarity of fossils several stratigraphical subdivisions based on lithological criteria have been established (see Schuler 1990). Strong intrabasinal variations of accommodation space, sediment supply as well as obvious base level fluctuations led to distinct facies changes and to the recurrent appearance of the same facies at several levels. Previous lithostratigraphical subdivisions remain, therefore, highly questionable and need to be 
revised. A sequential concept was developed by Duringer (1988) for the conglomerates and by BlancValleron (1991) for the evaporites of the southern and middle URG. Derer et al. (2003) applied a genetic concept to the Late Eocene to Early Oligocene syn-rift deposits within the northern URG.

\section{Lithofacies associations}

Several lithofacies associations (LFAs) formed recurrently in the different domains of the southern URG during the late Middle Eocene to Early Oligocene (Fig. 6). The following LFAs are distinguished:

Conglomerate LFA (alluvial fan); it forms a belt of alluvial fans along the margins of the southern URG (Duringer 1988). The conglomerates are mainly composed of Mesozoic limestone clasts that were eroded from the graben shoulders. Palaeocurrent directions imply transport towards the basin centre (Fig. 6). Continuous uplift and erosion of the graben flanks is documented by a stratigraphically inverse pebble petrography. The conglomerates interfinger with littoral sandstones and sometimes with variegated marls (Duringer 1988).

Variegated Marl LFA (alluvial plain); variegated marls are widespread in the uppermost part of the Salt Formation. In the lower part they are restricted to the marginal areas of the basin; they are reddish in colour and interfinger with thin conglomerates and probably represent alluvial plain deposits. In the basin centre, greenish, greyish and brownish colours suggest poorlydrained conditions.

Calcareous sandstone LFA (marginal lacustrine); it occurs basinward of the conglomerate fans. The sandstones are interbedded with variegated marls, lacustrine limestones and sometimes lignites. These deposits are called "Haustein" (Förster 1892); in this study the term "Haustein Facies" is used. It occurs along the margins of the basin, particularly in the southern graben domain. The depositional environments range from high-energy littoral settings, where cross-bedded, sometimes oolitic packstones are found, to low-energy deposits, including oncolites, stromatolites, fluviodeltaic wackestones and reed remains (Duringer and Gall 1994).

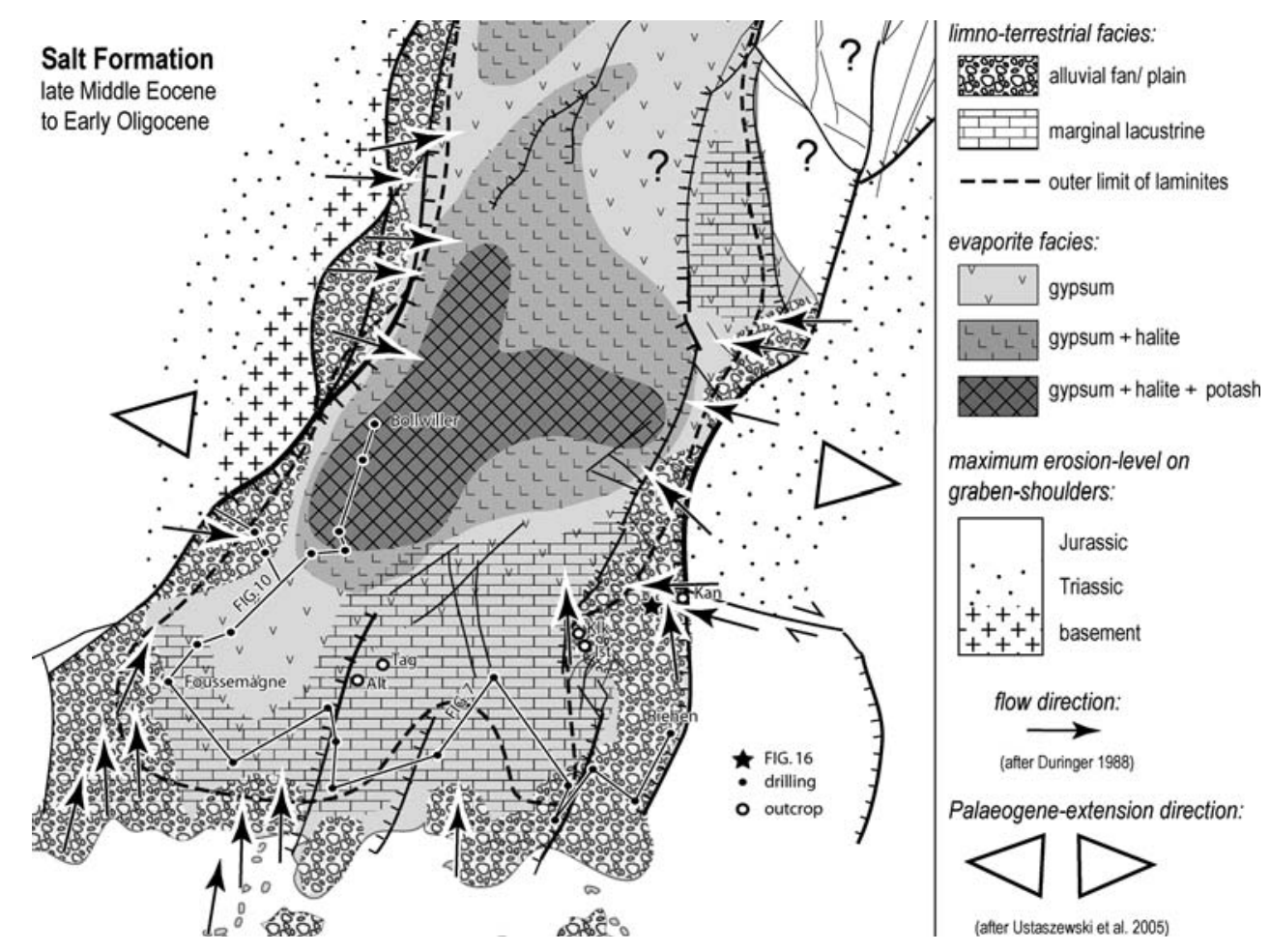

Fig. 6 Palaeogeographic map illustrating late Middle Eocene to Early Oligocene syn-rift sedimentation within the southern URG (modified from Duringer 1988; Blanc-Valleron 1991; own observations). A limno-terrestrial facies is found in the southernmost part of the graben and in the Freiburg Embayment comprising fluvial to shallow-water sediments (Calcareous Sandstone Lithofacies Association (LFA), Lacustrine Limestone
LFA), whereas the basin centre yields a thick sequence of marls and evaporites. Erosion of the rift flanks is documented in alluvial fans, which formed along the graben margins. Crystalline basement has been exhumed along the crest of the masterfault footwall during the Early Oligocene. Outcrops: Kan Kandern, Klk Kleinkems, Ist Istein, Tag Tagolsheim, Alt Altkirch 
Lacustrine limestone LFA (mainly shallow lacustrine); it occurs predominantly in the southern part of the graben, where it dominates the lower parts of the Salt Formation ("Melania Limestone", "Planorbis Limestone"). It often formed in the vicinity of the Haustein Facies. Oncolites, stromatolites and remains of characeans and reeds document a shallow lake setting (Stucky 2005). Often these deposits were pedogenetically overprinted (Stucky 2005) and, hence, are assigned to a palustrine facies (sensu Wright and Platt 1995). Towards the basin centre these limestones interfinger with grey to greenish marls.

Laminite LFA (moniolimnion of meromictic lake); it comprises rhythmically thin-bedded, laminated marls and lithographic limestones containing subordinate intercalations of grey, homogeneous marls. The laminites occur in the internal parts of the basin. Towards the basin margin, laminites interfinger with Haustein Facies (see below Fig. 8), as well as with lacustine limestones (well Heimersdorf 101; Vonderschmitt 1942). Several intervals contain monospecific mass occurrences of euryhaline taxa, insects and terrestrial plant remains (e.g. Förster 1892; Wappler et al. 2005). Especially the "Fossiliferous Zone", in the upper part of the Middle Salt Sub-Formation, represents a marker horizon, that can be traced almost basin-wide (Wappler et al. 2005).

Because the laminites are closely associated with evaporites (Förster 1892), they are assigned to a saline facies. They are interpreted to have been deposited in an open-water environment during a meromictic lake stage, when stagnant, highly saline, oxygen-depleted waters filled the deep part of the basin (moniolimnion), overlain by an almost pure freshwater lens (mixolimnion, Hofmann et al. 1993; Hinsken 2003). As permanent stratification of a water body requires a minimum water depth of several tens of metres (e.g. Wetzel 1991; Talbot and Allen 1996), the laminites are thought to represent a deepwater facies.

Grey and Green Marl LFA (e.g. open lake-brackish); it is the dominant lithology in the central part of the basin. It is interpreted as an open lake facies. However, it is not always possible to distinguish this facies from that of the Variegated Marl LFA in the sparse well-reports. Faunal remains indicate oscillations between an evaporitic and a freshwater environment (Blanc-Valleron and Schuler 1997).

Evaporite LFA (salt lake); it occurs in the Potash Basin and consists of gypsum, anhydrite, halite, and some potash salts (Fig. 6), that are generally interbedded with marls. The evaporites of the Middle and Upper Salt Sub-Formations preserve depositional fea- tures (Sturmfels 1943), whereas the evaporites of the Lower Salt Sub-Formation have been partly deformed by halokinesis (Blanc-Valleron and Schuler 1997). The potassium salts occur only within some seams at the base of the Upper Salt Sub-Formation and are restricted to the deepest part of the Potash Basin (see below).

\section{Basin-fill architecture}

The distribution of the different LFAs in space and time is used to outline the basin fill architecture (Figs. 6, 7, 8, 9, 10, 11). This is illustrated by a palaeogeographical map showing the distribution of characteristic lithofacies associations (Fig. 6), a few outcrop sections (Figs. 8a, 9), well sections (Figs. 9, 11) and cross-sections (Figs. 7, 8b, 10). The cross-sections shown in Fig. 7 and 10 are based on subsurface data.

Basin margin; the graben margins are characterized by a sharp termination of the Salt Formation against growth faults or extensional flexures, whereas the Grey Marls seem to onlap the Dinkelberg Block (Fig. 7; well Riehen and well Reinach).

Conglomerates attributed to the Middle and Upper Salt Sub-Formations are exposed about $15 \mathrm{~km}$ to the north near Kandern (Fig. 8a), where they unconformably rest on Mesozoic sediments, that have been affected by an extensional flexure (Fig. 8b). Based on fossils these lower intervals are allocated to the "Fossiliferous Zone" (Hinsken 2003; Stucky 2005). The clastics are covered by the open marine Grey Marl Formation. At the top a major stratigraphic gap occurs which is overlain by Neogene gravels.

Basel Block and Sierentz Block; sediment thickness of the individual stratigraphic units varies across faults implying sedimentation contemporaneous with faulting. Across these blocks sediment thickness increases towards the footwall testifying to a half graben setting, whereas the sedimentary facies on the individual blocks was quite uniform (Fig. 7). The separation of the Basel Block and Sierentz Block by the Allschwil Fault Zone probably occurred relatively late during the deposition of the Middle Salt Sub-Formation. This fault zone displaces a unit of Eocene lacustrine limestone that partly has been eroded on the footwall crest (well Allschwil 1, Schmidt et al. 1924). The crest area of the tilted Sierentz Block exhibits a shift towards a proximal facies and a drastically reduced sediment thickness (well Knoeringue). Further south, the Salt Formation is replaced by a hiatus (Ustaszewski et al. 2005a; well Sundgau 201).

Two major sections expose the Altkirch Block footwall crest (Fig. 9): At Tagolsheim about $40 \mathrm{~m}$ pe- 


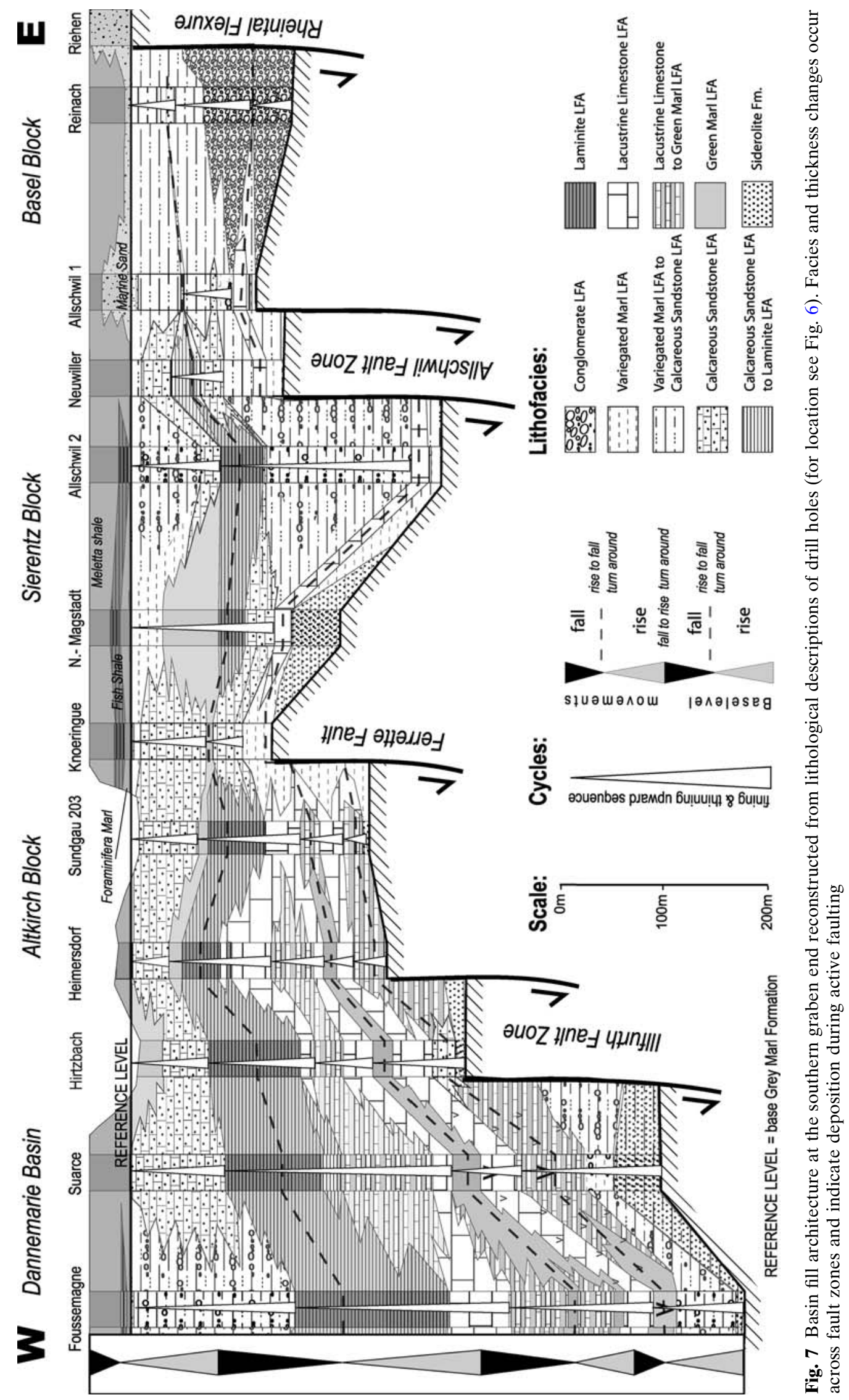


Fig. 8 Geological situation in the marginal part of the basin illustrated by three sections a from the SE basin margin (location see Fig. 6). Coarse conglomerates at the graben margin prograde blasinward into lacustrine deposits. At the borderfaults the conglomerates rest uncoformably on an extensional flexure (b)
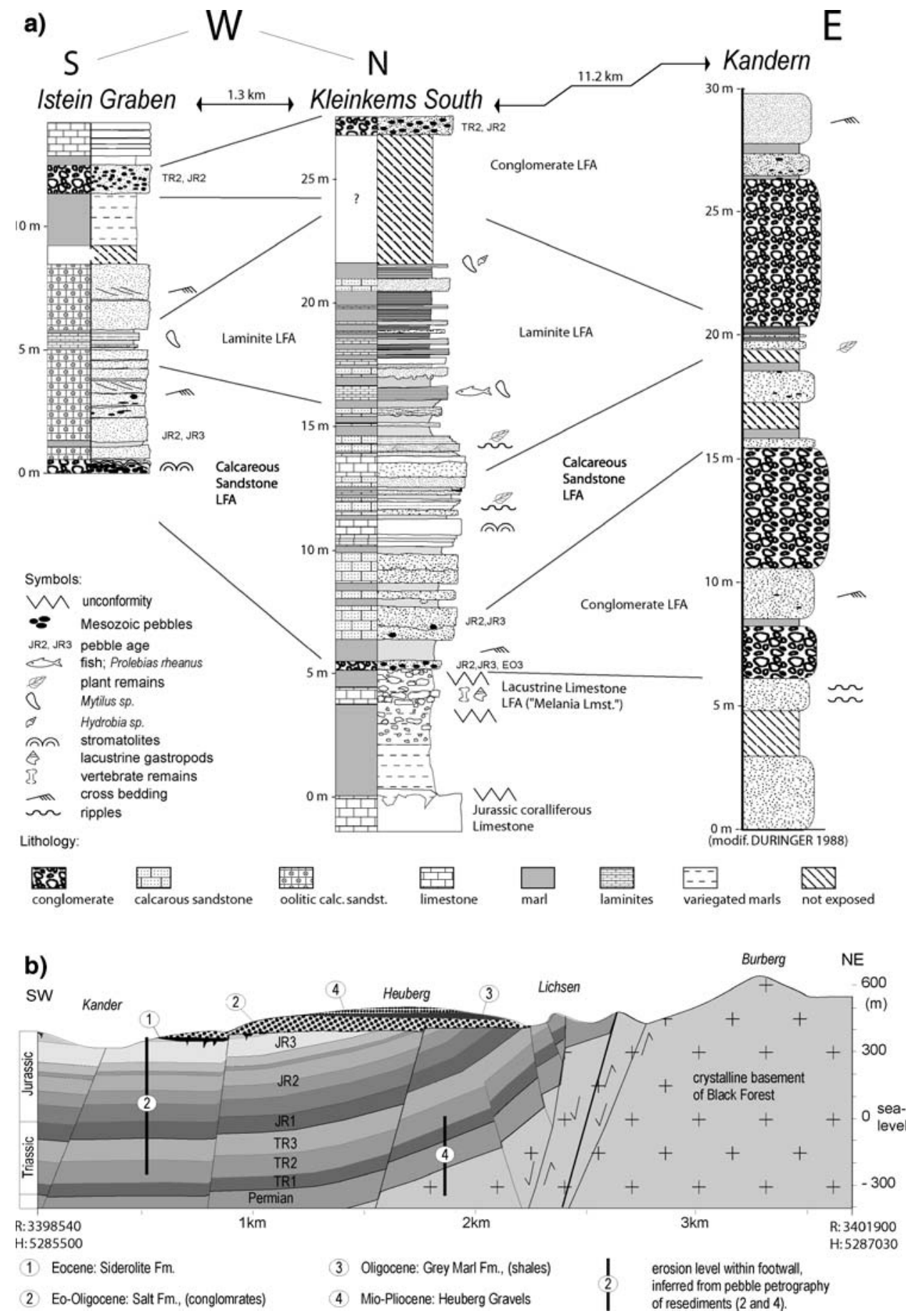

dogenetically modified lacustrine "Melania Limestone" are covered by the laminites of the "Fossiliferous Zone". At Altkirch the laminites of the "Fossiliferous Zone" are overlain by the "Haustein", which has been strongly affected by pedogenesis. The lowermost part of the Haustein shows an oolitic facies and includes intra- and extraformational pebbles.

Istein Block; the facies changes observed on the Basel and the Sierentz Block in wells are exposed on the Istein Block (Fig. 8a). Conglomerates interfinger with sandstones, laminites and limestones. The "Istein Graben" locality (e.g. Wittmann 1952) also exposes oolitic calcareous sandstones containing Mesozoic clasts, interbedded with conglomerates derived from Middle and Late Jurassic rocks and laminated carbonates preserving the characteristic fauna of the "Fossiliferous Zone". They are covered by variegated marls and conglomerates. 
Fig. 9 Sections exposed at the crest of the tilted Altkirch Block (for location see Fig. 6) correlated with the Heimersdorf well (Fig. 7). The Tagolsheim section (modified from Stucky 2005) exposes the "Melania Limestone" of Middle-Late Eocene age. The Altkirch quarry exposes laminites and the "Haustein" (Calcareous Sand LFA) in the top. "Melania Limestone" and "Haustein" are marginal lacustrine sediments that have been pedogenetically overprinted

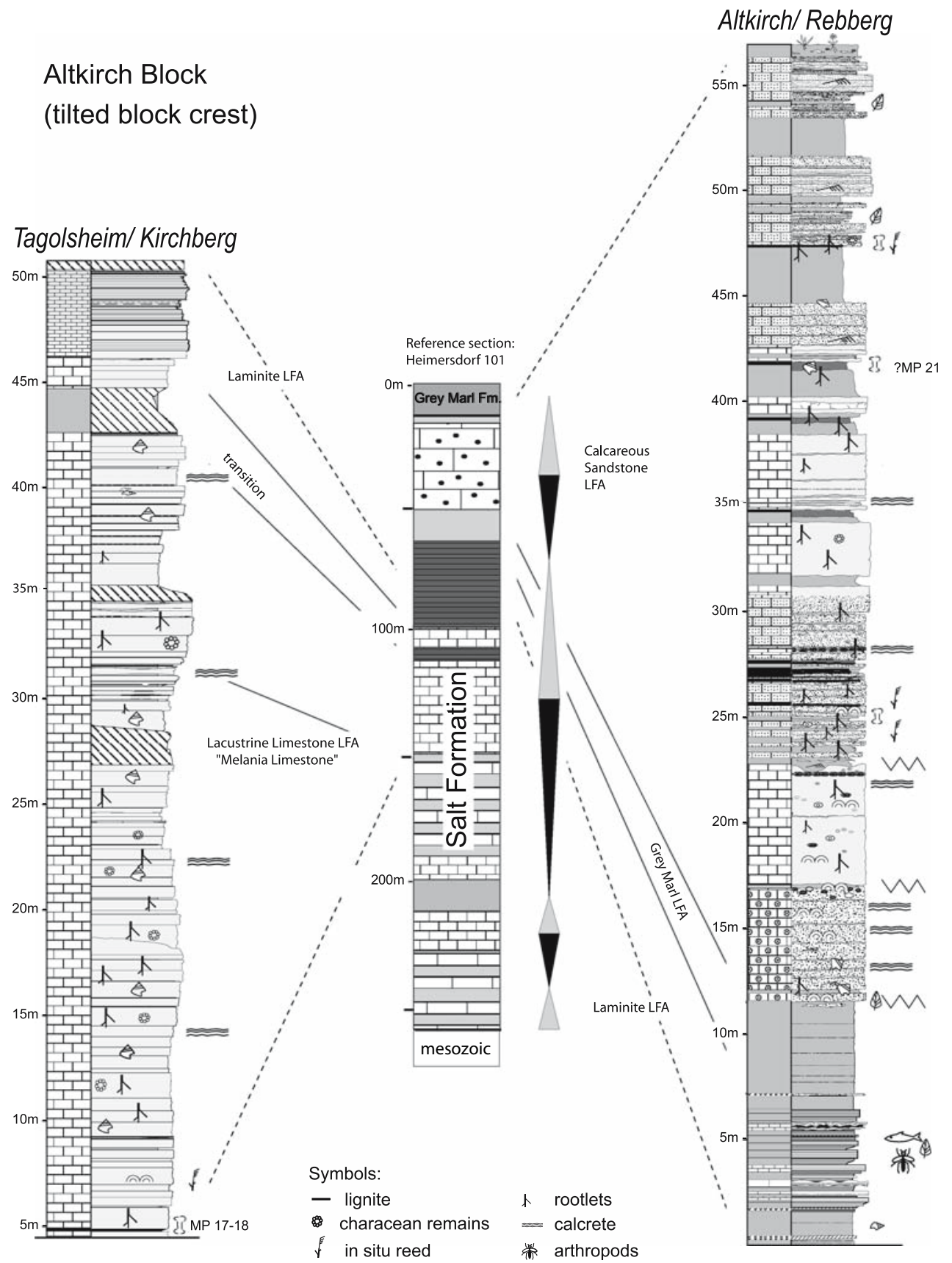

In the "Kleinkems South" section Late Jurassic limestones unconformably overlain by palaeosols are covered by variegated marls including reworked relicts of lacustrine "Melania Limestone". Conglomeratic calcareous sandstones follow above another erosional unconformity. They grade upward into the laminites of the "Fossiliferous Zone". The section ends with conglomerates.

Dannemarie Basin; at the south of the Dannemarie Basin the facies is similar to that on the Altkirch and the Sierentz Blocks (Fig. 7). Sediment thickness continuously increases towards the north (Fig. 10). Gyp- siferous marls become the prominent lithology while lacustrine limestones and "Haustein Facies" are drastically reduced in thickness (Fig. 11; Brechaumont well).

Potash Basin; further north, near Mulhouse, the facies changes abruptly. The occurrence of halite and potash salts characterizes the transition towards the Potash Basin. The fill of the central part of the Potash Basin is well documented (Fig. 11; well Staffelfelden 8/ 9). Three major evaporation cycles can be distinguished. The cycles show massive halite at the base, which is repeatedly interbedded with marls (second 






Fig. 11 Wells within the Dannemarie Basin and the Wittelsheim Sub-Basin (for location see Figs. 6, 10) show the facies distribution in the internal graben domains. The Staffelfelden $8 / 9$ well-log resembles the stratigraphical reference section of the Salt Formation and the underlying Middle Eocene. According to correlation by resistivity well-logs and application of a base-level concept, the major cycles can be traced throughout wide parts of the basin

order cycles) that become prominent towards the top of a cycle.

\section{Palaeogeography}

The environmental setting in the southern URG changed repeatedly between lacustrine, brackish and evaporitic. It is still a matter of debate, whether the southern URG was connected to the ocean during deposition of the Salt Formation or not (e.g. Wappler et al. 2005). Benthic foraminifera, dinoflagellate cysts, nanoplankton and bryozoans in several intervals of the Middle Salt Sub-Formation imply a marine influence (Förster 1892; Martini 1995; Blanc-Valleron and Schuler 1997). However, these taxa have been reported also from saline lakes (e.g. Tappan 1980; Rauscher et al. 1988; Fontes et al. 1991; Pawlowski and Holzmann 2002). The fauna is of low diversity and characterized by monospecific mass occurrences of opportunistic species indicating a rather restricted environment (Hinsken 2003). In addition, no euhaline marine macrofossil has yet been found (Fontes et al. 1991). Furthermore, the continuous rim of fluvial conglomerates around the basin (Wagner 1938; Duringer 1988; Derer et al. 2003) contradict a fully marine setting. The facies association in the southern URG (Figs. 6, 7,10) points to a typical continental evaporite basin with freshwater limestones surrounding the evaporites in the centre, as was described, for instance, in the Piceance Creek Basin (Green River Formation; Cole and Pickard 1981). Consequently, facies distribution and palaeoecology support the interpretation that the Salt Formation was at least for its major part deposited in a restricted to enclosed environment in a continental setting.

\section{Flank uplift}

The amount of graben-shoulder uplift can be estimated from pebble petrography. The local changes of the pebble petrography within the Conglomerate LFA along the Vosges, Black Forest and Jura Mountains suggest differential uplift of the rift flanks (e.g. Duringer 1988; Fig. 6). Strongest uplift occurred in the Vosges, where erosion reached the crystalline basement already during Early Oligocene (Upper Salt SubFormation). At the same time erosion in the Black Forest cut down to the Middle Triassic. In the northern Jura, erosion affected only Late Jurassic limestones. The uplift pattern derived from pebble composition is inverse to the subsidence pattern: in cross-section, the graben is deepest, where the flanks have been uplifted the most (deepest erosional truncation), like along the western rim of the Potash Basin.

\section{Sediment source}

Most of the graben-fill sediments were delivered from the graben flanks (e.g. Roll 1979). Only little sediment was derived from the Jura representing the Alpine forebulge during the Late Eocene (Kempf and Pfiffner 2004). However, sediment input from the north (e.g. Gaupp and Nickel 2001) might have occurred due to 
the erosion on the Rhenish Massif (see Ziegler 1990). The southward increase of evaporites and the carbonate facies along the southernmost graben margins point to clastic supply from the north, rather than from the south.

The composition of the lacustrine deposits in the southern graben is largely controlled by the lithology in the catchment area (e.g. Talbot and Allen 1996). The Mesozoic strata along the rift flanks probably supported carbonate sedimentation at the lake margins and marl accumulation in the open lake. Erosion of Triassic evaporites is regarded to be the main source for the salts (e.g. Gale 1920; Duringer 1988; Fontes et al. 1991), as pebbles of the Triassic salt-bearing strata are frequently found within the Conglomerate LFA, and the amount of halite dissolved on the graben shoulders exceeded that deposited in the graben (Blanc-Valleron 1991). Furthermore the isotopic composition of gypsum suggests a Triassic rather than a Tertiary marine origin (Fontes et al. 1991).

\section{Sediment partitioning and $A / S$-ratio}

The facies distribution within the southern URG was strongly affected by accommodation space as well as sediment supply (Figs. 6, 7, 10). As accommodation space was often filled up to the base level, especially at the margins of the basin, sediment partitioning played a major role during the filling of the basin. Therefore, the ratio of accommodation space $(A)$ and sediment supply $(S)$, the $A / S$-ratio, was the main factor controlling sediment partitioning and facies distribution.
Low A/S-ratio at graben margins; high sediment supply from the rising flanks, but low subsidence led to the formation of wedge-shaped conglomerate and sandstone bodies along the graben borders. Locations of major sediment infill appear to be spatially related to active transfer zones and the intersection of reactivated lineaments (see below). A large fan delta system developed west of Mulhouse (e.g. well Michelsbach, well Guewenheim) between the Dannemarie Graben and the Wittelsheim Sub-Basin in front of the recent valley of the river Thur, which follows a major lineament.

The central Potash Basin was bordered by a conglomerate belt sometimes only a few hundreds of metres wide (e.g. Schreiner 1977). This points to a low sediment input in front of the strongly uplifted footwalls along the margins of the Potash Basin. Intraformational pebbles of lacustrine limestones along the graben margins (e.g. Kiefer 1928; Genser 1959; Fig. 8a) point to sediment cannibalism during times of low base-level.

Medium A/S-ratio on intrabasinal swells; low subsidence and low sediment input characterize the intrabasinal highs. Similarly, the crests of tilted blocks received little or no clastic sediment. At such sites carbonates dominate (Figs. 8, 9, 10) and sometimes even oolite shoals formed. Frequently, the deposits became exposed (during low base-level) and were subject to pedogenesis (Fig. 9).

High A/S-ratio in the Potash Basin; in the Potash Basin at high subsidence rates the sediment input was on average low (Fig. 11). Evaporites formed during
Fig. 12 Facies diagram illustrating the interpreted basin-fill architecture and the major base-level cycles of the Eo-Oligocene syn-rift sediments in the southern URG

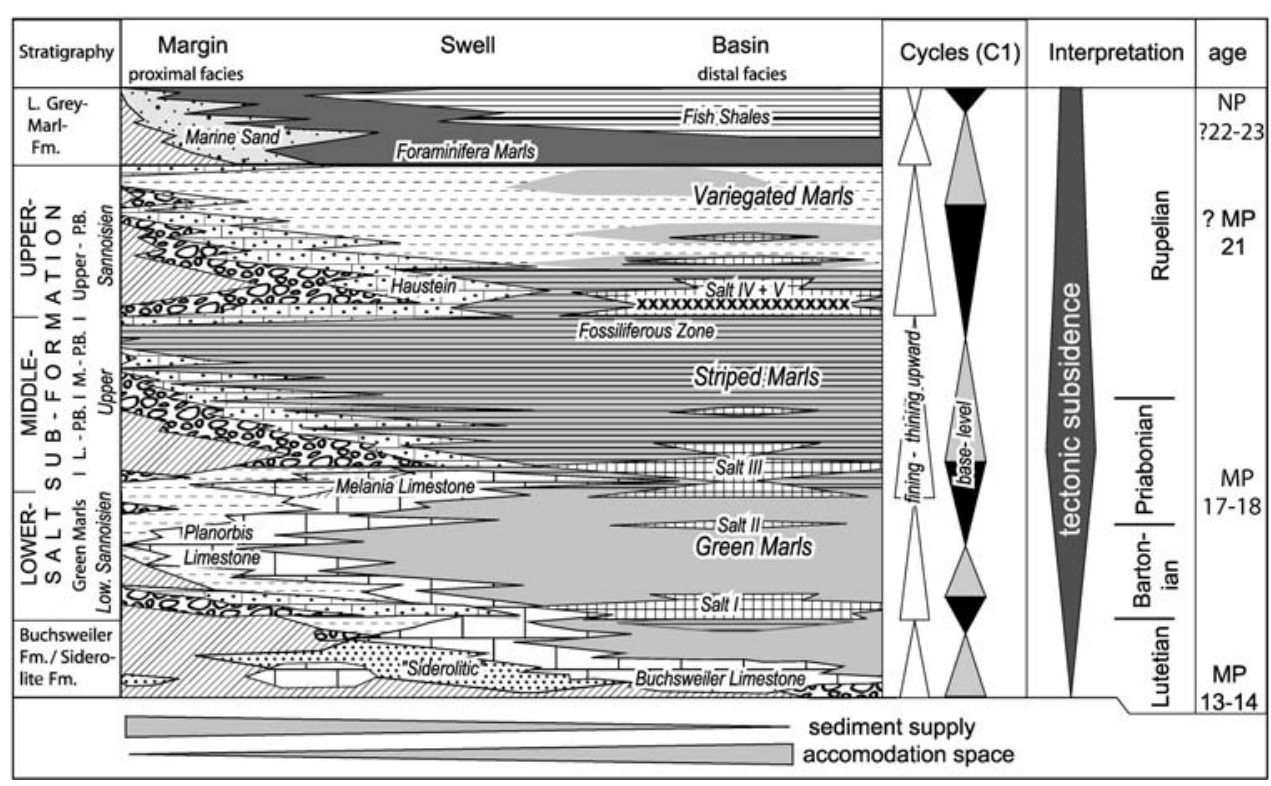


times of increased aridity and there was almost no terrigenous supply. Marls accumulated during relatively humid periods.

\section{Age constraints}

The age of the members of the Salt Formation has not been well established yet because of sparse and equivocal biostratigraphical data (e.g. Berger et al. 2005b; Wappler et al. 2005; Fig. 12). A maximum age of the Lower Salt Sub-Formation can be estimated by the Lutetian age (zone MP13-14) of the basal Siderolite Formation and Buchsweiler Formation (e.g. Berger et al. 2005b). The gradual transition from the Siderolite Facies to the Green Marl Facies reported from many drill holes contradicts a postulated Bartonian unconformity within the southern URG (e.g. Sissingh 1998; Schumacher 2002). A mammalian fauna recently discovered in the lower part of the "Melania Limestone" at Tagolsheim (Stucky 2005) has provided a preliminary age of stage MP 17-18 corresponding to the Early Priabonian (B. Engesser, personal communication). Thus, the oldest part of the Lower Salt SubFormation must be Bartonian or even Lutetian in age (see Fig. 9).

The low diverse, but abundant nanoplankton community within the upper part of the Middle Salt SubFormation in the "Fossiliferous Zone" can be correlated with the Middle Pechelbronn Beds and, hence, implies an Early Oligocene age (Martini 1995). Mammalian remains from the "Haustein Member" at Altkirch provide an Early Oligocene age (MP 21; B. Engesser, personal communication). A minimum age of the Upper Salt Sub-Formation is given by the overlying Foraminifera Marls that belong to Nanoplankton Zone NP ?22-23 (middle Rupelien; Berger et al. 2005b).

Further age estimates rely on the correlation with strata in the middle and northern URG. The Green Lymnea Marls (Middle Eocene) are seen as correlative with the Lower Salt Sub-Formation (e.g. Berger et al. 2005b). The Lower Pechelbronn Beds are correlated with the lower part of the Middle Salt Sub-Formation and represent the Late Eocene (e.g. Berger et al. 2005b). The Middle Pechelbronn Beds are regarded to have a Late Eocene to Early Oligocene age (Gaupp and Nickel 2001). The Upper Pechelbronn beds are correlated with the Upper Salt Sub-Formation and point to an Early Oligocene to Middle Oligocene age (Gaupp and Nickel 2001).

As the deposition of the Salt Formation appears to be climatically controlled, enhanced evaporation in neighbouring basins, in particular the Paris Basin, provide useful additional information (e.g. Blanc-Valleron 1991). Based on the biostratigraphical results, Salt I might correspond to the Lutetian-Bartonian evaporation cycle in the Paris Basin, Salt II and Salt III to the Late Priabonian evaporation cycles during which the "Gypse de Montmartre" formed (see Rouchy 1997).

Sedimentary dynamics and base-level fluctuations

\section{Tripartite lake model}

Because of the great variability of environmental settings and the disputed connection to the ocean the base-level concept was chosen to subdivide the deposits of the Salt Formation. However, instead of the classic correlation of $A / S$-ratio cycles (sensu Cross and Lessenger 1998) the base-level concept of a triple stage lake model was applied (Bohacs et al. 2000). This approach represents a slight modification of the classical base-level concept, which better fits the palaeogeographic conditions in the southern URG. The tripartite lake model (sensu Bohacs et al. 2000) distinguishes between overfilled, balanced and underfilled basin mode.

During an overfilled basin mode the base-level was high due to decreased subsidence or increased supply of water and sediment; a freshwater lake formed in the basin. Carbonates accumulated along the margins and marls in the central part.

During an underfilled basin mode base-level was low due to increased subsidence and/or decreased supply of water and sediment. Evaporites accumulated in the basin centre. Distinct alluvial fans developed on the graben margins, favoured by extended slopes. The marginal parts of the basin were characterized by deposition of variegated marls or the formation of palaeosols.

A balanced basin mode occurred during transitional periods. Water stratification resulted from superficial freshwater inflow onto a saline brine and led to a meromictic lake stage. Carbonate sedimentation dominated in shallow lake areas. A base-level fall resulted in fan delta progradation, while base level rise resulted in fan delta retreat (Duringer 1988).

\section{Cycles}

Three major evaporation cycles formed in the Potash Basin (Figs. 11, 12). Each cycle starts with thick halite beds, which decrease in abundance and thickness towards the top, and finally grade into marls. They represent first order base-level rise cycles, which define the 
Lower, Middle and Upper Salt Sub-Formations. According to the stratigraphic age estimates, each cycle may have had a duration of approximately $3 \mathrm{My}$. Major fining-upward cycles at the graben borders are correlated with the base-level rise cycles of the subformations.

Second order cycles are expressed by interbedding of single layers (e.g. halite, marl) and show a drastically reduced, probable allocyclically controlled frequency (Blanc-Valleron 1991). Along the basin margins and on intra-basinal highs first order cycles are often asymmetrically developed and show dominantly base-level rise tendency, whereas base-level falls seem to be represented by an unconformity (Fig. 8). Cycles as well as facies along the margins of the basin are well correlatable with the strata of comparable thickness within the northern URG (see Derer et al. 2003). Towards the basin centre lower order cycles become increasingly pronounced. The subcycles exhibit a tendency towards symmetrical base-level cycles.

Although the three salt sub-formations are similar with respect to the general trends, they show considerable differences in their depositional style.

The Lower Salt Sub-Formation is characterized by greyish to greenish marls and evaporites in the basin centre as well as abundant limestones in the marginal parts. Lateral sediment supply was low. Laminites are restricted to the depo-centres. A relatively low relief and moderate basin subsidence is suggested for the Lower Salt Sub-Formation.

The Middle Salt Sub-Formation is characterized by increased clastic supply from the graben shoulders, abundant carbonate sedimentation on swells and abundant "deep-water" laminites within the basin. All these features point to the formation of a distinct relief and thus to enhanced subsidence.

The Upper Salt Sub-Formation records a basinward progradation of clastic wedges in its lower part and a transition towards a fluvio-terrestrial environment in the higher parts. Both trends imply a transition towards an overfilled basin and indicate peneplainisation of the relief due to decreased rifting.

\section{Tectonic implications}

The spatial distribution of facies and sediment thicknesses provides some information about subsidence. Little shifting of syn-rift facies belts implies uniform subsidence and a pure extensional stress regime with a constant extension direction during such a period. However, in the southern graben a shift of the area of maximum subsidence from $\mathrm{W}$ to $\mathrm{E}$ is observed, which has been interpreted to have resulted from a transition from oblique to orthogonal extension (Schumacher 2002). Syn-rift sediment thicknesses and facies changes suggest that subsidence was strongest in the Potash Basin and decreased towards the southern and northern graben domains.

Long-term changes (several My) of the depositional setting are interpreted to be of tectonic origin. Theoretically, increased rifting results in distal facies in the basin centre and proximal facies along the borders. Decreased rifting leads to propagation of marginal facies basinwards (decrease in accommodation space). Therefore, the Middle Salt Sub-Formation, characterized by deep-water environments in the basin interior and the onset of strong clastic supply from the graben shoulders, probably represents the climax of rifting.

\section{Formation of the southern Upper Rhine Graben}

\section{Basin geometry}

The width of the southern URG has been determined by locating its break-away faults and by measuring it parallel to the Palaeogene extension direction (mean azimuth of $095^{\circ}$; Ustaszewski et al. 2005a), which is more or less perpendicular to the graben's strike (Fig. 6). The graben width varies between $63 \mathrm{~km}$ in its southernmost part near Basel, $35 \mathrm{~km}$ in the area of the Potash Basin to the north of Mulhouse, and about $\geq 50 \mathrm{~km}$ in the area of Colmar. This along-strike change in rift width is accompanied by a change of graben depth (Cloos 1939), and sedimentary facies (Figs. 3, 6). Within this context it is important to recall that the development of the URG was pre-determined by (the reactivation of) pre-existing Late Palaeozoic crustal discontinuities.

Extension, graben width and subsidence

The amount of extensional displacement $(\Delta L)$ across the URG is in the order of $5 \mathrm{~km}$, as estimated from several cross-sections (see below). This value appears to be constant along the entire graben (Sittler 1969; Laubscher 1970; Doebl and Teichmüller 1979; Villemin et al. 1986; Durst 1991; Brun et al. 1992). However, as the present day, "final" rift width $\left(L_{f}\right)$ varies along strike, $\Delta L$ is partitioned over a variably wide zone in the different graben segments. Therefore, differences in the initial rift width $\left(L_{0}\right)$ are responsible for variations in the crustal stretching factor $(\beta)$, which mainly controls the extensional-basin subsidence (Allen and Allen 2005). 
Fig. 13 Effect of rock volume balance at constant extension $\Delta L$. a Rift basin subsidence depends largely on graben width $L_{f}$ (i versus ii) and depth to detachment $Z_{\mathrm{d}}$ (i versus iii). b Consequently an axial depo-centre develops in a narrow rift zone, if $\Delta L$ and $Z_{\mathrm{d}}$ are constant



$\beta$ can be calculated from $\Delta L$ and is related to $L_{0}$ by

$\beta=\Delta L / L_{0}+1$.

$\Delta L$ and observed $L_{f}$ are related by

$L_{0}=L_{f}-\Delta L$.

Substituting Eq. 2 into 1, $\beta$ can be alternatively expressed as:

$\beta=\Delta L /\left(L_{f}-\Delta L\right)+1$.

In this equation the direct dependence of $\beta$ and the observed $L_{f}$ can be shown, especially if $\Delta L$ stays constant along strike of the graben.

Moreover, graben-subsidence is related to the compensation depth of extensional faulting $\left(Z_{\mathrm{d}}\right.$; depth to detachment sensu Groshong 1996), which is generally associated with the sole-out level of listric faults forming on a common detachment. This can be shown by rift volume balancing (Fig. 13a).

Rift volume balancing (e.g. Groshong 1996) is another method to calculate $\Delta L$ independently from line length balancing (retro-deformation) of a cross-section (if $Z_{\mathrm{d}}$ is known), or to estimate $Z_{\mathrm{d}}$ (if $\Delta L$ is known) using the graben volume $V_{R}$ (Fig. 13a). In cross-section, $V_{R}$ is defined as the so-called "lost area" ( $A_{\text {lost }}$; Groshong 1996) between the pre-rift and the present position of a reference level (e.g. top of basement). If the rock volume did not change (i.e. if volcanism is excluded), the "lost area" equals the so-called "won area", which compensates the displacement above $Z_{\mathrm{d}}$.
$Z_{\mathrm{d}}$ and $\Delta L$ are related by:

$Z_{\mathrm{d}}=A_{\text {lost }} / \Delta L$.

Assuming that $\Delta L$ and $Z_{\mathrm{d}}$ (and thus $A_{\text {lost }}$ ) of the evolving graben remain constant along its strike, then depocentres evolve within narrow graben segments (small $L_{0}$, high $\beta$ ), whereas shallow basins develop in the wide parts of the graben (large $L_{0}$, low $\beta$; Fig. 13b, 14a; Eq. 3).

The same effect occurs in the case of block tilting (Fig. 14), which frequently occurs in lithospheric-scale extensional basins (e.g. Leeder and Gawthorpe 2002) and that is generally regarded to be the surface expression of listric faulting, soling out on a common detachment at $Z_{\mathrm{d}}$. Block tilting therefore enables the rift volume to be balanced if $\Delta L$ is partitioned over a variable rift width and among a variable number of fault-bounded tilted blocks (Figs. 14b).

\section{Extension in the URG}

To test the hypothesis developed above, $\Delta L, A_{\text {lost }}$ and $Z_{\mathrm{d}}$ were estimated from two cross-sections in the study area (Fig. 4). $\Delta L$ was measured along the top of the pre-Mesozoic basement. $A_{\text {lost }}$ was constructed using the same reference level, and a top-line connecting both break-away faults at reference level, as is shown in Fig. 14b. For section B-B', located in the shallow southernmost part of the URG (Figs. 3, 4), line-length balancing yielded a $\Delta L$ of $4.2 \mathrm{~km}$ (Ustaszewski 2004). This value appears to be very reliable, because the 
Fig. 14 Effect of block tilting on extensional basin formation, where $\Delta L$ is partitioned among several normal faults heaves $(\delta l)$; a map view, b cross-sections. A symmetrical tilt-block graben of constant $\Delta L$ develops a local depo-centre and highest graben shoulder uplift in a narrow rift zone, especially if the graben opens splay-like (cross-section $a$ ). Thereby the graben volume and the dip of normal faults are almost constant. Small letters refer to cross-sections marked in $(a)$
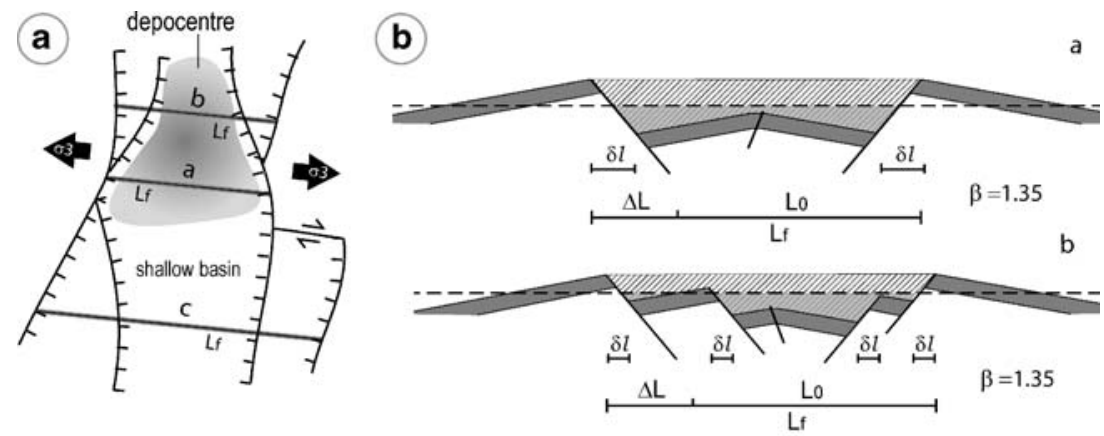

a



reference horizon can be traced over most of this crosssection. For section $\mathrm{A}-\mathrm{A}^{\prime}$, the base of the Mesozoic was first extrapolated over the crests of the grabenshoulders, assuming negligible basement erosion there (in agreement with Paul 1955). Line-length balancing for section $\mathrm{A}-\mathrm{A}^{\prime}$ yields a $\Delta L$ of about $4.5 \mathrm{~km}$. Measurement of $A_{\text {lost }}$ provides $111 \mathrm{~km}^{2}$ in cross-section B$\mathrm{B}^{\prime}$, while it results in $121 \mathrm{~km}^{2}$ for cross-section $\mathrm{A}-\mathrm{A}^{\prime}$. Using Eq. 4, $Z_{\mathrm{d}}$ yields almost $27 \mathrm{~km}$ for both crosssections. The values estimated for both cross-sections are in a reasonable agreement. However, $\Delta L$ and $A_{\text {lost }}$ are about $10 \%$ less in cross-section B-B'.

The calculated $Z_{\mathrm{d}}$ values are in a good agreement with the Moho-depth of about $27 \mathrm{~km}$ in the area adjacent to the URG (see Dèzes et al. 2004). This suggests that the whole crust was affected by brittle tectonics and the compensation depth of extensional faulting is located in the proximity of the Moho (in agreement with Groshong 1996). Indeed, the crustal configuration of the URG (Brun et al. 1992) and the occurrence of earthquakes almost down to the Moho in its southern parts (Plenefisch and Bonjer 1997) imply that the crust behaves in a brittle manner at present. The observed strong syn-rift uplift of the graben flanks is compatible with flexural rebound due to a very deep level of necking (see Kooi and Cloetingh 1992) located within the upper mantle and proves the assumption that the entire crust was affected by brittle tectonics during Palaeogene extension.

In order to get further information about extension in the URG, $A_{\text {lost }}$ was measured from several published cross-sections (Fig. 15; Table 1) and the calculated $Z_{\mathrm{d}}$ of $27 \mathrm{~km}$ was used to estimate $\Delta L$ (Eq. 4). All cross-sections show a similar $A_{\text {lost }}$ of about $120 \mathrm{~km}^{2}$



Fig. 15 Location of cross-sections mentioned in Table 1. Section 1 from Wenzel et al. (1991), section 2 and 3 from Doebl and Teichmüller (1979), section A-A' this work, section B-B' from Ustaszewski (2004)

and point to a constant extension of about $4.5 \mathrm{~km}$. However, isostatic flexural rebound affects $A_{\text {lost }}$ and the measured values might be slightly underestimated (calculated $\Delta L$ to small). $\Delta L$ directly measured from seismic sections (line length balancing), may also be 
Table 1 Measured $A_{\text {lost }}$ and calculated $\Delta L$ values for several published cross-sections in the URG applying volume balancing with a $Z_{\mathrm{d}}$ of $27 \mathrm{~km}$

\begin{tabular}{lcc}
\hline Section & $A_{\text {lost }}\left(\mathrm{km}^{2}\right)$ & $\Delta L(\mathrm{~km})$ \\
\hline 1 & $\geq 101$ & $\geq 3.7$ \\
2 & 127.6 & 4.7 \\
3 & 129.9 & 4.8 \\
A-A' & 121 & 4.5 \\
B-B' & 112 & 4.13 \\
\hline
\end{tabular}

Location of the sections is shown in Fig. 15. For section 1 an accurate $A_{\text {lost }}$ value cannot be given, because the base-Mesozoic reference-level has been eroded before rifting

somewhat smaller than the actual value because smallscale faults are below the resolution and therefore not taken into account. The real $\Delta L$ may be marginally higher and a $\Delta L$ of $5 \mathrm{~km}$ appears to be a realistic value for the Cenozoic URG.

\section{Rift basin formation}

Obviously, the Potash Basin is located in the deepest and narrowest part of the southern URG $\left(L_{f} \approx 35 \mathrm{~km}\right)$ for which a high average stretching factor $(\beta \approx 1.14)$ has been determined (sect. 3 in Fig. 16). This depocentre was already bordered during the Palaeogene by

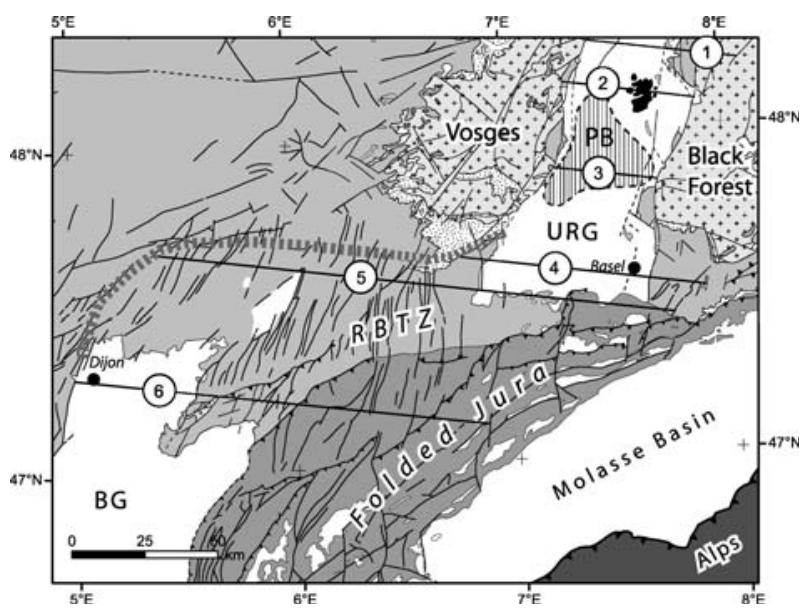

Fig. 16 Tectonic interpretation of the Palaeogene southern URG and the Rhine-Bresse Transfer Zone (RBTZ). An almost constant total crustal extensional strain of about $5 \mathrm{~km}$ has been distributed within several graben domains of variable width (black bars). The orthogonally rifted Potash Basin (PB), representing the narrowest part of the graben, experienced an average strain of about $14 \%$ extension, resulting in strong subsidence and pronounced graben shoulder uplift, whereas the obliquely rifted Rhine-Bresse Transfer Zone experienced only about $2 \%$ extensional strain, resulting in negligible subsidence and the formation of a swell, which acted as barrier towards the Molasse Basin and the Bresse Graben (BG) strongly elevated rift flanks. Therefore, the Potash Basin is regarded as a narrow basin with a relatively high $\beta$ value.

To the north, the Potash Basin shallows and narrows as the graben, including the shallow Freiburg Embayment, widens to $L_{f} \approx 43 \mathrm{~km}$ ("2" in Fig. 16) near Freiburg. This suggests that in this area $\Delta L$ was partitioned over a wider zone and a larger number of faults than in the central parts of the Potash Basin. North of Freiburg, where the Elzach Fault branches off from the Black Forest Border Fault, the rift zone widens to $L_{f} \approx 55 \mathrm{~km}$ (at N-end of Elzach Fault) whilst the URG shallows, forming the Colmar Swell ("1" in Fig. 16).

South of Mulhouse ("4" in Fig. 16), the URG widens from $L_{f} \approx 41 \mathrm{~km}$ to $L_{f} \approx 63 \mathrm{~km}$ across the Kandern-Hausen Fault. This increase in graben width coincides with a distinct decrease in the thickness of Palaeogene syn-rift sediments and a pronounced change from the Potash Basin deep-water and/or evaporite facies to the shallow-water and/or terrestrial facies domain of the southernmost URG. This part of the graben is characterized by an average stretching factor $(\beta \approx 1.07)$ and is thus regarded as a low- $\beta$ basin, consisting of several tilted blocks (Fig. $4 \mathrm{~b}$ ). South of the Kandern-Hausen Fault, the elevation of the Black Forest rift flank decreased during the Palaeogene rifting phase, as evidenced by a change in the pebble petrography and the flow directions of alluvial fans in the Kandern area (Fig. 17). The Kandern Fan prograded westward and contains Middle Jurassic to Middle Triassic pebbles, reflecting strong uplift of the hinterland being located to the north of the KandernHausen Fault. By contrast, the Holzen Fan and Hammerstein Fan prograded north- and north-westward and contain only Late Jurassic pebbles. This indicates decreased uplift of the hinterland, which was located south of the Kandern-Hausen Fault, and strong subsidence of the graben north of this fault.

Still further south, the diffuse sinistrally transtensive Rhine-Bresse Transfer Zone (RBTZ; Laubscher 1970; Illies 1981; Lacombe et al. 1993; Ustaszewski et al. 2005b) extends from the Wehra-Zeiningen Fault Zone in the east to the northern part of the Bresse Graben near Dijon in the west and beyond into the Massif Central over a distance of more than $200 \mathrm{~km}$ (" 5 " in Fig. 16). This transfer zone is regarded as a very wide, obliquely rifted domain (Illies 1981) that is characterized by a very low stretching factor $(\beta \approx 1.02)$. This interpretation is compatible with the local occurrence of monocline-bounded basins (e.g. Delsberg Basin) containing only thin Late Eocene and Early Oligocene sediments within the domain of RBTZ (Laubscher 1998; Berger et al. 2005a). 


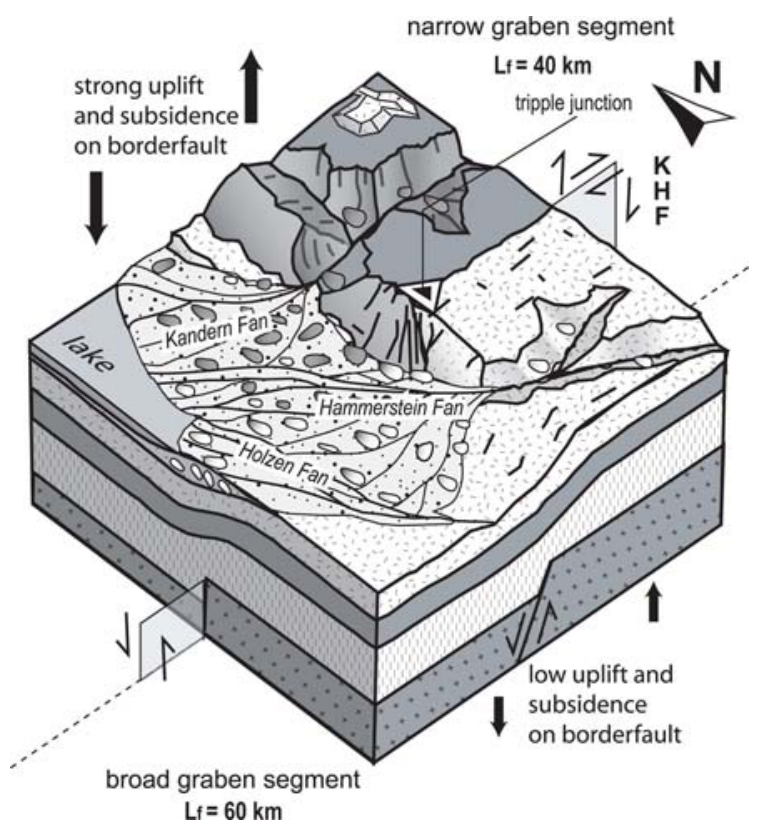

Fig. 17 Alluvial fan configuration observed near Kandern (for location see Fig. 6) at the triple junction of the eastern main border fault and Kandern-Hausen Fault $(K H F)$. The Kandern Fan prograded westward and the age of the pebbles ranges from Middle Jurassic to Middle Triassic. The Hammerstein Fan and the Holzen Fan prograded northwest/northward and include almost exclusively Late Jurassic limestone pebbles. The specific alluvial fan configuration points to greater throw on border fault in the narrow graben segment northern the KHF as well as decreased throw on normal faults south of the KHF, along which the graben broadens to the south by about $20 \mathrm{~km}$

The RBTZ is superimposed onto a WSW-ENE trending, Permo-Carboniferous trough system; its faults were repeatedly reactivated during the evolution of the URG and the Bresse Graben (Ustaszewski et al. 2005b). Partial decoupling of the Mesozoic cover from the basement during their reactivation played an important role in the development of the $\mathrm{N}-\mathrm{S}$ and NNE-SSW trending fault system that characterizes the RBTZ (Fig. 16).

\section{Discussion and conclusions}

The rift-related subsidence of the southern parts of the URG commenced during the Middle Eocene, increased during the Late Eocene-earliest Oligocene and decreased considerably during the Middle Oligocene. Miocene termination of rift-subsidence of the southern parts of the URG and deep erosional truncation of their syn-rift sediments is related to lithospheric folding controlling rapid uplift of the Vosges-Black Forest Arch (Dèzes et al. 2004).

For the Palaeogene evolution of the southern parts of the URG, Chorowicz and Defontaines (1993),
Schumacher (2002), Behrmann et al. (2003), Bertrand et al. (2005) and Schwarz and Henk (2005) postulated oblique rifting. However, there is no evidence for a temporal shift of facies belts during the Middle Eocene to Early Oligocene in the URG. Based on the presented results, Palaeogene extension across the southern URG was almost perpendicular to the rift axis and normal faulting occurred along its break-away faults. However, contemporaneous transtensional faulting occurred along transfer faults across which the initial rift width $\left(L_{0}\right)$ increased/decreased (e.g. KandernHausen Fault).

The Potash Basin is located in the deepest and narrowest part of the southern URG. Facies analyses indicate that this basin was under-filled most of the time during early Bartonian, Priabonian and early Oligocene times, when the Salt Formation accumulated. Evaporites formed in the central basin part and alluvial fans prograded from the rift flanks. Mechanisms controlling the development of the three first order evaporite depositional cycles are still a matter of dispute. Duringer (1988) attributed the development of these first order cycles to climatic controls. Although deposition of evaporites is obviously climatically controlled, almost all levels of the Salt Formation do indeed contain evaporitic layers that can be related to a second order climatic cyclicity. For the Pechelbronn Beds in the northern parts of the URG, which are time equivalent to the Salt Formation, Derer et al. (2003) implied a eustatic signal. However, it has as yet to be unequivocally established that the URG was connected to marine realms during this time span. Our results strongly suggest tectonic controls on the development of accommodation space and therefore the observed first order cyclicity reflects tectonic cycles that governed the shift towards an underfilled basin mode in response to accelerated subsidence. Nonetheless, the factors leading to development of the observed first order cycles are still controversial.

As a first approximation the URG presumably represented during Middle Eocene to Early Oligocene times an enclosed depositional system that was affected by along-strike variations in accommodation space, which in turn was governed by changes in the initial graben width $L_{0}$ and local clastic supply from the uplifted rift flanks. The initial graben width largely resulted from pre-existing crustal discontinuities that were reactivated under the prevailing stress regime (Schumacher 2002; Dèzes et al. 2004; Ustaszewski et al. 2005a).

Across the URG the total extensional displacement $\Delta L$ amounts to about $5 \mathrm{~km}$ and appears to be rather constant along strike, likewise $Z_{\mathrm{d}}$, which appears to be 
located near the Moho. The constancy of $\Delta L$ and $Z_{\mathrm{d}}$ resulted in a graben volume $V_{R}\left(A_{\text {lost }}\right)$ being almost constant along strike. However, the extensional displacement was partitioned over variably wide graben segments $\left(L_{f} \approx 35-65 \mathrm{~km}\right)$ with narrow graben segments corresponding to relatively high- $\beta$ basins (e.g. Potash Basin) and wide segments to relatively low- $\beta$ basins (e.g. southernmost part of URG around Basel).

Acknowledgments This work was performed under the umbrella of the EUCOR-URGENT-PROJECT (http://www.comp1. geol.unibas.ch). We wish to thank Philippe Elsass (BRGM Strasbourg) and Peter Huggenberger (Basel) for providing access to unpublished well data. We are grateful to Peter Ziegler (Basel) and Daniel Bernoulli (Basel) for carefully reading the manuscript, and to our colleagues Stefan Schmid, Markus Schumacher, Pierre Dèzes, Horst Dresmann, James McKenzie, Achim Stucky and Silvio Lauer (all at Basel) for helpful discussions and/or for technical support. Constructive comments by Jan-Diederik van Wees (Utrecht) and Gerhard Greiner (Berlin) helped to improve the manuscript.

\section{References}

Allen PA, Allen JR (2005) Basin analysis: principles and applications, 2nd edn. Blackwell, Oxford, pp 549

Becker A (2000) The Jura Mountains-an active foreland foldand-thrust belt? Tectonophysics 321:381-406

Behrmann J, Herman O, Horstmann M, Tanner DC, Bertrand G (2003) Anatomy and kinematics of oblique continental rifting revealed: a three-dimensional case study of the southeast Upper Rhine Graben (Germany). Am Assoc Petrol Geol Bull 87:1105-1121

Berger JP, Reichenbacher B, Becker D, Grimm M, Grimm K, Picot L, Storni A, Pirkenseer C, Derer C, Schaefer A (2005a) Paleogeography of the Upper Rhine Graben (URG) and the Swiss Molasse Basin (SMB) from Eocene to Pliocene. Int J Earth Sci 94:697-710

Berger J-P, Reichenbacher B, Becker D, Grimm M, Grimm K, Picot L, Storni A, Pirkenseer C, Schaefer A (2005b) Eocene-Pliocene time scale and stratigraphy of the Upper Rhine Graben (URG) and the Swiss Molasse Basin (SMB). Int J Earth Sci 94:711-731

Bertrand G, Horstmann M, Hermann O, Behrmann JH (2005) Retrodeformation of the southern Upper Rhine Graben: new insights on continental oblique rifting. Quat Sci Rev 24:347-354

Blanc-Valleron M-M (1991) Les formations Paléogènes évaporitiques du Bassin Potassique de Mulhouse et des Bassins plus septentrionaux d'Alsace. Doc BRGM, Orléans, pp 350

Blanc-Valleron M-M, Schuler M (1997) The salt basins of Alsace (Southern Rhine Graben). In: Brusson G, Schreiber BC (eds) Sedimentary deposition in Rift and Foreland Basins in France and Spain (Paleogene and Lower Neogene). Columbia University Press, New York, pp 95-135

Bohacs KM, Carroll AR, Neal JE, Mankiewicz PS (2000) Lakebasin type, source potential and hydrocarbon character: an integrated sequence-stratigraphic-geochemical-framework. In: Gierlowski-Kordesch EH, Kelts KR (eds) Lake basins through space and time. Am Assoc Petrol Geol Stud Geol 46:3-43
Boigk H, Schöneich H (1970) Die Tiefenlage der Permbasis im nördlichen Teil des Oberrheingrabens. In: Illies JH, Mueller S (eds) Graben problems. Schweizerbart, Stuttgart, pp 45-55

Brun JP, Gutscher MA, DEKORP-ECORS Team (1992) Deep crustal structure of the Rhine Graben from DEKORPECORS seismic reflection data. Tectonophysics 208:39-147

Chorowicz J, Defontaines B (1993) Transfer faults and pull-apart model in the Rhinegraben from analyses of multisource data. J Geophys Res 98:14339-14351

Cloos H (1939) Hebung-Spaltung-Vulkanismus. Geol Rundsch 30:401-527

Cole RD, Pickard MD (1981) Sulfur-isotope variations in marginal lacustrine rocks of the Green River Formation, Colorado and Utah. In: Eathridge FG, Flores RM (eds) Recent and ancient nonmarine depositional environments: models for exploration. Soc Econ Paleont Mineral Spec Publ 31:261-275

Courtot C, Gannat E, Wendling E (1972) Le Bassin Potassique de Mulhouse et ses environs. Étude du Tertiaire. Sci Géol Bull 25:69-91

Cross TA, Lessenger MA (1998) Sediment volume partitioning: rationale for stratigraphic model evaluation and high-resolution stratigraphic correlation. In: Gradstein FM, Sandvik KO, Milton NJ (eds) Sequence stratigraphy-concepts and applications. Norw Petrol Soc (NPF) Spec Publ, vol 8, pp 171-195

Derer C, Kosinowski M, Luterbacher HP, Schäfer A, Süss MP (2003) Sedimentary response to tectonics in extensional basins: the Pechelbronn Formation (Late Eocene to Early Oligocene) in the northern Upper Rhine Graben, Germany. In: McCann T, Saintot A (eds) Tracing tectonic deformation using the sedimentary record. Geol Soc (London) Spec Publ, vol 208, pp 55-69

Dèzes P, Schmid SM, Ziegler PA (2004) Evolution of the European Cenozoic Rift System: interaction of the Alpine and Pyrenean orogens with their foreland lithosphere. Tectonophysics 389:1-33

Doebl F, Teichmüller R (1979) Zur Geologie und heutigen Geothermik im mittleren Oberrhein-Graben. Fortschr Geol Rheinld Westf 27:1-17

Duringer P (1988) Les conglomérats des bordures du rift cénozoique rhénan. Dynamique sédimentaire et contrôle climatique. PhD Thesis, Institut de Géologie, Université Louis Pasteur, pp 278

Duringer P, Gall J-C (1994) Morphologie des constructions microbiennes en contexte de fan-delta Oligocène. Exemple du rift rhénan (Europe occidentale). Palaeogeogr Palaeoclimatol Palaeoecol 107:35-47

Durst H (1991) Aspects of exploration history and structural style in the Rhine graben area. In: Spencer AM (ed) Generation, accumulation and production of Europe's hydrocarbons. Eur Assoc Petrol Geosci Spec Publ, vol 1, pp 247-261

Echtler HP, Chauvet AC (1992) Carboniferous convergence and subsequent crustal extension in the southern Schwarzwald (SW Germany). Geodin Acta 5:37-49

Fischer H (1969) Geologischer Überblick über den südlichen Oberrheingraben und seine weitere Umgebung. Regio Basilensis 10:57-84

Fontes J-C, Filly A, Gaudant J, Duringer P (1991) Origine continentale des évaporites paléogènes de Haute Alsace: arguments paléoécologiques, sédimentologiques et isotopiques. Bull Soc Géol Fr 162:725-737

Förster B (1892) Geologischer Führer für die Umgebung von Mülhausen i. E. Strassburger Druckerei und Verlagsanstalt, Strassburg, pp 111 
Franke W (1989) Tectonostratigraphic units in Variscan belt of central Europe. Geol Soc Am Spec Pap 230:67-90

Gale HS (1920) The Potash deposits of Alsace. US Geol Surv Bull 715:17-55

Gaupp R, Nickel B (2001) Die Pechelbronnschichten im Raum Eich-Stockstadt (Nördlicher Oberrheingraben; Blatt 6216 Gernsheim). Geol Jb Hessen 128:19-27

Genser H (1959) Stratigraphie und Tektonik der Vorbergzone am südwestlichen Schwarzwaldrand zwischen Staufen und Badenweiler. Ber Naturf Ges Freiburg i Br 49:59-112

Geyer OF, Gwinner MP (1986) Geologie von Baden-Württemberg. Schweizerbart, Stuttgart, p 472

Giamboni M, Ustaszewski K, Schmid SM, Schumacher ME, Wetzel A (2004) Plio-Pleistocene transpressional reactivation of Paleozoic and Paleogene structures in the RhineBresse Transform Zone (northern Switzerland and eastern France). Int J Earth Sci 93:207-223

Gradstein F, Ogg J, Smith A (2004) A geologic time scale. Cambridge University Press, Cambridge, p 589

Groshong RH (1996) Construction and validation of extensional cross-sections using lost area and strain, with the application to the Upper Rhine Graben. In: Buchanan PG, Nieuwland DA (eds) Modern developments in structural interpretation. Geol Soc Am Spec Publ, vol 99, pp 79-87

Hauber L (1991) Ergebnisse der Geothermiebohrungen Riehen 1 und 2 sowie Reinach 1 im Südosten des Rheingrabens. Geol Jb E48:167-184

Hinsken S (2003) Geologische Untersuchungen an Syn-Riftsedimenten des südlichen Oberrheingrabens. MSc Thesis, Geologisch-Paläontologisches Institut, Universität Basel, p 285

Hofmann P, Huc AY, Carpentier B, Schäffer P, Albrecht P, Keely B, Maxwell JR, Sinninghe Damsté JW, De Leeuw JW, Leythaeuser D (1993) Organic matter of the Mulhouse Basin, France: a synthesis. Org Geochem 20:1105-1123

Huber B (1994) Rupelian foraminifera in the southern Rhinegraben and their paleoecological significance. $\mathrm{PhD}$ Thesis, Geologisch-Paläontologisches Institut, Universität Basel, p 92

Illies JH (1981) Mechanisms of graben formation. Tectonophysics 73:249-266

Illies JH, Greiner G (1978) Rhine Graben and Alpine System. Geol Soc Am Bull 89:770-782

Kälin D (1997) Litho- und Biostratigraphie der Mittel- bis Obermiozänen Bois de Raube-Formation (Nordwestschweiz). Eclogae Geol Helv 90:97-114

Keller J, Kramel M, Henjes-Kunst F (2002) ${ }^{40} \mathrm{Ar} /{ }^{39} \mathrm{Ar}$ single crystal laser dating of early volcanism in the Upper Rhine Graben and tectonic implications. Schweiz Mineral Petrogr Mitt 82:1-10

Kempf O, Pfiffner AO (2004) Early Tertiary evolution of the North Alpine Foreland Basin and adjoining areas. Basin Res 16:549-567

Kiefer H (1928) Das Tertiär der Breisgauer Vorberge zwischen Freiburg i Br und Badenweiler. Ber Naturf Ges Freiburg i Br 28:1-98

Kooi H, Cloetingh S (1992) Lithospheric necking and regional isostasy at extensional basins 2. Stress induced vertical motions and relative sea level changes. J Geophys Res 97:17573-17592

Kuhlemann J, Spiegel C, Dunkl I, Frisch W (1999) A contribution to the paleogeography of central Europe: new evidence from fission track ages of the southern Rhine-Graben. $\mathrm{N} \mathrm{Jb}$ Geol Paläont Abh 214:415-432

Lacombe O, Angelier J, Byrne D, Dupin J (1993) EoceneOligocene tectonics and kinematics of the Rhine-Saone continental transform zone (Eastern France). Tectonics 12:874-888

Larroque J, Ansart M (1984) Étude des fentes d'extension liées à la tectonique distensive du bassin potassique oligocène de Mulhouse. C R Acad Sci (Paris) 299:1419-1424

Laubscher H (1970) Grundsätzliches zur Tektonik des Rheingrabens. In: Illies JH, Mueller S (eds) Graben problems. Schweizerbart, Stuttgart, pp 79-86

Laubscher H (1998) Der Ostrand des Laufenbeckens und der Knoten von Grellingen: Die verwickelte Begegnung von Rheingraben und Jura. Eclogae Geol Helv 91:275-291

Laubscher H (2001) Plate interactions at the southern end of the Rhine graben. Tectonophysics 343:1-19

Laubscher H (2004) The southern Rhine graben: a new view of the initial phase. Int J Earth Sci 93:341-347

Leeder MR, Gawthorpe RL (2002) Sedimentary models for extensional tilt-block/half-graben basins. In: Holdsworth RE, Turner JP (eds) Extensional tectonics: regional-scale processes. Key issues in Earth sciences, Geol Soc (London), vol 1, pp 171-184

Le Carlier de Veslud C, Bourgeois O, Diraison M, Ford M (2005) 3D stratigraphic and structural synthesis of the Dannemarie Basin (Upper Rhine Graben). Bull Soc Géol Fr 176:433-442

Löschke J, Güldenpfennig M, Hann HP, Sawatzki G (1998) Die Zone von Badenweiler-Lenzkirch (Schwarzwald): Eine variskische Suturzone. Zeitschr Dtsch Geol Ges 149:197-212

Lutz M, Cleintuar M (1999) Geological results of a hydrocarbon exploration campaign in the southern Upper Rhine Graben. Bull Appl Geol 4:3-80

Manz O (1934) Die Ur-Aare als Oberlauf und Gestalterin der pliozänen Oberen Donau (Teil 1). Hohenzoller Jh 1:113-160

Martini E (1995) Kalkiges Nannoplankton aus dem UnterOligozän von Morvillars, Territoire de Belfort, Frankreich. Jber Mitt Oberrhein Geol Ver NF 77:265-269

Metz R (1970) Dehnungsstrukturen im Grundgebirge des Schwarzwalds vor Beginn der Grabentektonik. In: Illies JH, Mueller S (eds) Graben problems. Schweizerbart, Stuttgart, pp 79-86

Müller WH, Naef H, Graf HR (2002) Geologische Entwicklung der Nordschweiz, Neotektonik und Langzeitszenarien, Zürcher Weinland. NAGRA Tech Ber 99-08, 237 pp

Paul W (1955) Zur Morphogenese des Schwarzwalds. Jh Geol LAmt Baden-Württ 1:395-427

Pawlowski J, Holzmann M (2002) Molecular phylogeny of Foraminifera-a review. Eur J Protistol 38:1-10

Plenefisch T, Bonjer K-P (1997) The stress field in the Rhine Graben area inferred from earthquake focal mechanisms and estimations of frictional parameters. Tectonophysics 275:71-97

Rauscher M, Schuler M, Sittler C (1988) Les dinokystes dans le Paléogène d'Alsace: Le problème de l'origine du sel. C R Acad Sci Paris II:175-178

Roll A (1979) Versuch einer Volumenbilianz des Oberrheintalgrabens und seiner Schultern. Geol Jb A52:3-82

Rollier L (1911) Révision de la stratigraphie et de la tectonique de la Molasse au Nord des Alpes en général et de la Molasse subalpine suisse en particulier. N Denkschr Schweiz Naturf Ges 46:1-89

Rotstein Y, Schaming M, Rousse S (2005) Structure and tertiary tectonic history of the Mulhouse High, Upper Rhine Graben: block faulting modified by changes in the alpine stress regime. Tectonics 24:TC6001

Rouchy JM (1997) Palaeogene continental rift system of Western Europe: introduction and stratigraphy In: Busson G, Schreiber BC (eds) Sedimentary deposition in rift and 
foreland basins in France and Spain (Paleogene and Lower Neogene). Columbia University Press, New York, pp 43-94

Schmidt C, Braun L, Paltzer G, Mühlberg M, Christ P, Jacob F (1924) Bohrungen von Buix bei Pruntrut und Allschwil bei Basel. Beitr Geol Schweiz Geotech Ser 10:1-74

Schmidt-Kittler N (1987) International symposium on mamalian biostratigraphy and Palaeoecology of the European Paleogene. Münchner Geowiss Abh 10:1-312

Schnarrenberger C (1925) Kalisalz und Erdöl im Rheintal. Niederschrift über die Versammlung der Direktoren der geologischen Landesanstalten des Deutschen Reiches und Deutsch-Österreichs. Preuss Geol. L-Anst, Berlin, pp 1-12

Schreiner A (1977) Tertiär. In: Erläuterungen zur Geologischen Karte von Freiburg und Umgebung (1:50 000). Landesvermessungsamt Baden-Württ, Stuttgart, pp 133-153

Schuler M (1990) Environments et paléoclimats Paléogènes: palynologie et biostratigraphie de l'Eocène et l'Oligocène inférieur dans les Fossés Rhénan, Rhodanien et de Hesse. Doc BRGM 190, pp 535

Schumacher ME (2002) Upper Rhine Graben: role of preexisting structures during rift evolution. Tectonics 21:6-1-6-17

Schwarz M, Henk A (2005) Evolution and structure of the Upper Rhine Graben: insights from three-dimensional thermomechanical modelling. Int J Earth Sci 94:732-750

Sissingh W (1998) Comparative Tertiary stratigraphy of the Rhine Graben, Bresse Graben and Molasse Basin: correlation of Alpine foreland events. Tectonophysics 300:249-284

Sittler C (1969) Le Fossé Rhénan en Alsace. Aspect structural et histoire géologique. Rev Géogr Phys Géol Dyn 11:465-494

Stucky A (2005) Der Melanienkalk im südlichen Oberrheingraben: Sedimentationsdynamik pedogenetisch alterierter Karbonate (Tagolsheim, Elsass). MSc Thesis, GeologischPaläontologisches Institut, Universität Basel, 131 pp

Sturmfels E (1943) Das Kalisalzlager von Buggingen (Südbaden). N Jb Min Geol Paläont Abh A78:131-216

Talbot MR, Allen PA (1996) Lakes. In: Reading HG (ed) Sedimentary environments: processes, facies and stratigraphy. Blackwell, Oxford, pp 83-123

Tappan H (1980) The paleobiology of plant protists. Freeman, San Francisco, p 1028

Timar-Geng Z, Fügenschuh B, Wetzel A, Dresmann H (2006) Low-temperature thermochronology of the flanks of the southern Upper Rhine Graben. Int J Earth Sci 95:685-702

Todorov I, Schegg R, Wildi W (1993) Thermal maturity and modelling of Mesozoic and Cenozoic sediments in the south of the Rhine Graben and the Eastern Jura (Switzerland). Eclogae Geol Helv 86:667-692

Ustaszewski K (2004) Reactivation of pre-existing crustal discontinuities: the southern Upper Rhine Graben and the northern Jura Mountains - a natural laboratory. PhD Thesis, Geologisch-Paläontologisches Institut, Universität Basel, pp 176

Ustaszewski K, Schumacher ME, Schmid SM (2005a) Simultaneous normal faulting and extensional flexuring during rifting - an example from the southernmost Upper Rhine Graben. Int J Earth Sci 95:680-696

Ustaszewski K, Schumacher ME, Schmid SM, Nieuwland D (2005b) Fault reactivation in brittle-viscous wrench systems-dynamically scaled analogue models and application to the Rhine-Bresse Transfer Zone. Quat Sci Rev 24:363380

Villemin T, Alvarez F, Angelier J (1986) The Rhinegraben: extension, subsidence and shoulder uplift. Tectonophysics 128:47-59

Villinger E (1998) Zur Flussgeschichte von Rhein und Donau in Südwestdeutschland. Jber Mitt Oberrh Geol Ver NF 80:361-398

Vonderschmitt L (1942) Die geologischen Ergebnisse der Bohrungen von Hirtzbach bei Altkirch (Ober-Elsass). Eclogae Geol Helv 35:67-99

Wagner W (1938) Das Unteroligozän (Sannoisien) im Rheintalgraben unter Berücksichtigung seiner Lagerstätten. Notizbl Hess Geol L-Anst 5:120-149

Wappler T, Hinsken S, Brocks JJ, Wetzel A, Meyer CA (2005) A fossil sawfly of the genus Athalia (Hymenoptera: Tentheredinidae) from the Eocene-Oligocene boundary of Altkirch, France. C R Palevol 4:7-16

Wenzel F, Brun J-P, ECORS-DEKORP working group (1991) A deep reflection seismic line across the Northern Rhine Graben. Earth Planet Sci Lett 104:140-150

Wetzel A (1991) Stratification in black shales: depositional models and timing - an overview. In: Einsele G, Ricken W, Seilacher A (eds) Cycles and events in stratigraphy. Springer, Berlin, pp 508-523

Wetzel A, Allenbach R, Allia V (2003) Reactivated basement structures affecting the sedimentary facies in a tectonically "quiescent" epicontinental basin: an example from NW Switzerland. Sedim Geol 157:153-172

Wimmenauer W (1977) Junger Vulkanismus. Erläuterungen zur Geologischen Karte von Freiburg und Umgebung (1:50 000). Vermessungsamt Baden-Württ, Stuttgart, pp 133-153

Wittmann O (1952) Erläuterungen zu Blatt Lörrach und Blatt Weil. Kommissionsverlag Herder \& Co, Freiburg, p 68

Wright VP, Platt NH (1995) Seasonal wetland carbonate sequences and dynamic catenas: a re-appraisal of palustrine limestones. Sedim Geol 99:65-71

Ziegler PA (1990) Geological atlas of Western and Central Europe. Shell Internationale Petroleum Maatschappij B.V. Den Haag, p 238

Ziegler PA, Schumacher ME, Dèzes P, van Wees J-D, Cloetingh $S$ (2004) Post-Variscan evolution of the lithosphere in the Rhine Graben area: constraints from subsidence modelling. In: Wilson M, Neumann E-R, Davies GR, Timmerman MJ, Heeremans M, Larsen BT (eds) Permo-Carboniferous magmatism and rifting in Europe. Geol Soc (London) Spec Publ, vol 223, pp 289-317 